\title{
Effect of added magnesium, potassium, lime and nitrogen on oats II. Nutrient contents, cation ratios and magnesium uptake
}

\author{
RAILI Jokinen \\ Agricultural Research Centre, Department of Agricultural Chemistry and Physics \\ 01300 Vantaa 30, Finland
}

\begin{abstract}
In a pot experiment on sphagnum peat soil the magnesium fertilization increased significantly the magnesium content of the grains and the straws of oats. The addition of potassium fertilization decreased the magnesium content when the plants received a magnesium fertilization. Without magnesium the rate of potassium fertilization did not have an effect on the magnesium content of the straws. The increase in the equivalent ratio of the three potassium rates and the two magnesium rates decreased the magnesium content of both the grains and the straws. Along with the magnesium fertilization the addition of lime decreased the magnesium content of the grains and increased that of the straws. Doubling the amount of the nitrogen fertilization with the magnesium fertilizer increased the magnesium content of the grains and the straws. In the case of magnesium deficiency the addition of lime or nitrogen did not have an effect on the magnesium content of the yields.

The rate of magnesium, potassium, lime and nitrogen did not have an effect on the potassium content of the grains. The potassium content of the straws increased with the addition of potassium. Without the magnesium fertilization the potassium content, as well as, the ratios $\mathrm{K} / \mathrm{Mg}$ and $\mathrm{K} /(\mathrm{Ca}+\mathrm{Mg})$ in the grains and the straws were high. A part of the missing magnesium had, perhaps, been substituted for by potassium.

The calcium content of the grains and the straws obtained without magnesium fertilization was significantly higher than the calcium content with magnesium fertilization. The oats substituted possibly in part also calcium for the missing magnesium.

The effect of added magnesium, potassium, lime and nitrogen on the magnesium uptake by oats was discussed.
\end{abstract}

\section{Introduction}

The positive effect on the magnesium content of the grains of cereals caused by magnesium fertilization has been rather slight both in pot experiments and in field experiments (Lehne and Koepke 1962, Jokinen and Simojoki 1975, JøRGENSEN 1976). The advantageous effect of the magnesium fertilization has been greater on the magnesium content of cereal shoots harvested before the heading (JERLSTRÖM 1975) as well as on that of the straws (JøRGENSEN 1976) than on the magnesium content of the grains. 
It has been proposed that the decrease in the magnesium content or in the magnesium uptake by plants due to potassium fertilization is caused by the antagonism between potassium and magnesium (WELTE and Werner 1963, Alston $1966 \mathrm{~b}$ ). On the other hand, it has been observed that the shortage of a certain cation causes an increase in the uptake of other cations (Grimme et al. 1974, Mengel et al. 1976). According to Terman et al. (1975) it is possible to obtain definite information about the antagonism between cations only if the addition of the nutrients does not have an effect on the yield.

In a pot experiment on a mineral soil the use of lime lowered the magnesium content of barley harvested before heading (JERLSTRöm 1975). The competition between calcium and magnesium in oat shoots was not strong (ALston 1966 a, 1966 b). In solution-culture experiments (FALADE 1973) an increase in the magnesium content of a nutrient solution caused a decrease in the calcium content of corn shoots.

The total quantity of cations taken up by plants increases as a result of the extent of nitrogen fertilization increasing, and nitrogen in nitrate form raises the quantity of the cations more clearly than the nitrogen in ammonium form (HANSEN 1972). In rield experiments the addition of nitrogen fertilizer promoted the uptake of potassium, calcium and magnesium into green oats (HÅLAND 1971).

The purpose of this experiment is to clarify the effect of magnesium, potassium and nitrogen fertilization, as well as that of lime supply, on the nutrient content and on the magnesium uptake of oat grains and straws thus treated. The significance of the combination effects of the nutrients will also be studied.

\section{Material and methods}

In a pot experiment, carried out in factorial design, were studied the effects of three different rates of magnesium $\left(\mathrm{Mg}_{0}=0, \mathrm{Mg}_{1}=200\right.$ and $\mathrm{Mg}_{2}=400$ $\mathrm{mg} /$ pot $\mathrm{Mg}$ ), of three rates of potassium $\left(\mathrm{K}_{1}=415, \mathrm{~K}_{2}=830\right.$ and $\mathrm{K}_{4}=$ $1660 \mathrm{mg} /$ pot $\mathrm{K})$, two of lime $\left(\mathrm{Ca}_{1}=2400\right.$ and $\mathrm{Ca}_{3}=7200 \mathrm{mg} /$ pot $\left.\mathrm{Ca}\right)$ and of two of nitrogen $\left(\mathrm{N}_{1}=1000\right.$ and $\mathrm{N}_{2}-2000 \mathrm{mg} /$ pot $\left.\mathrm{N}\right)$ on the nutrient contents, the cationic ratios and the magnesium uptake of the grain and the straw yields of oats during three seasons. As the growth base in 5 liters Mitscherlich-pots was used $250 \mathrm{~g}$ of air-dry Sphagnum-peat ${ }^{2} \mathrm{pH}_{\mathrm{H}_{2}} \mathrm{O}$ 4.2). A more detailed description of the experiment has been presented previously (JoKINEN 1977).

The total nitrogen was determined for the grain and straw samples by means of the Kjeldal-method. The magnesium, potassium and calcium contents of the plant samples were determined by means of atomic absorption spectrophotometry from ash obtained by dry ashing $\left(500^{\circ} \mathrm{C}\right)$ and extracting into $0.1 \mathrm{~N}$ hydrochloric acid. In the calcium and magnesium determinations the interferences were eliminated by using $5 \%$ La-solution. The nutrient contents are expressed as $\mathrm{mg} / \mathrm{g}$ dry-matter.

In the statistical treatment of the data the same methods were used as in the testing of the yields. 


\section{Results}

\section{Magnesium content of grains and straws}

Magnesium fertilization increased in all the years significantly the magnesium content of both the grains and the straws regardless of the rate of liming, and potassium and nitrogen fertilization (Table 1). The magnesium content of the yields increased as the rate of magnesium fertilization was increased.

The magnesium content of the grains received with the magnesium fertilization remained almost constant from year to year, even though the fertilization was reneved yearly. The coefficient of variation in all the data was 0.21 for the magnesium content of the grains and 0.58 for the magnesium content of the straws.

The effect of the three different potassium rates used in the experiment did not differ from each other as far as the effect on the magnesium content of the grains was concerned, when there was no magnesium fertilization. The magnesium content of the straws, on the other hand, decreased due to the effect of the potassium fertilization in the first and the second years in yields which had received an abundant nitrogen fertilization and liming. Quantities of potassium fertilizer supplied along with the magnesium fertilization did not alter the magnesium content of the grains, either. The magnesium content of the corresponding straw yields decreased year by year, and the difference in the magnesium content with the greatest potassium rate and with the smallest one was significant.

The equivalent ratios between the three rates of potassium $(415 \mathrm{mg}=$ $10.6 \mathrm{me}, 830 \mathrm{mg}=21.2 \mathrm{me}$ and $1660 \mathrm{mg}=42.5 \mathrm{me}$ ) and the two rates of magnesium ( $200 \mathrm{mg}=16.5 \mathrm{me}$ and $400 \mathrm{mg}=32.9 \mathrm{me})$ in the annual fertilization were $0.32,0.65,1.29$ and 2.58 . The magnesium content of the grains and the straws of oats depended on the variations of the ratio $\mathrm{K} / \mathrm{Mg}$ in all the data on the average as follows:

\begin{tabular}{|c|c|c|c|c|}
\hline & \multicolumn{4}{|c|}{$\mathrm{K} / \mathrm{Mg}$ in the fertilization } \\
\hline & 0.32 & 0.65 & 1.29 & 2.58 \\
\hline & \multicolumn{4}{|c|}{$\mathrm{Mg} \mathrm{mg} / \mathrm{g}$} \\
\hline (1) & $1.5^{\mathrm{d}}$ & $1.4^{\mathrm{e}}$ & $1.3^{\mathrm{b}}$ & $1.2^{\mathrm{a}}$ \\
\hline Straws & $2.6^{\mathrm{d}}$ & $2.0^{\mathrm{e}}-\mathrm{r}-\mathrm{l}$ & $1.7 \mathrm{~b}$ & $1.2^{\mathrm{a}}$ \\
\hline
\end{tabular}

An increase of the ratio from 0.32 to 2.58 decreased the magnesium content of the grains by $20 \%$ and that of the straws by $54 \%$. The differences between the magnesium contents in the grains on one hand, and in the straws on the other hand, obtained with all the different values of the ratio, were significant.

Tripling the rate of lime had in some cases a slight positive effect on the magnesium content of the grains (the first year), while in other cases (the third year) the effect was negative. The magnesium content of the straws increased significantly in the first two years as lime was added, and most clearly at the low potassium level. In the third year also the magnesium content of the straws was depressed as the lime rate was increased at the highest potassium rate. 
Table 1. Magnesium content of grains and straws ( $\mathrm{Mg} \mathrm{mg} / \mathrm{g}$ dry matter).

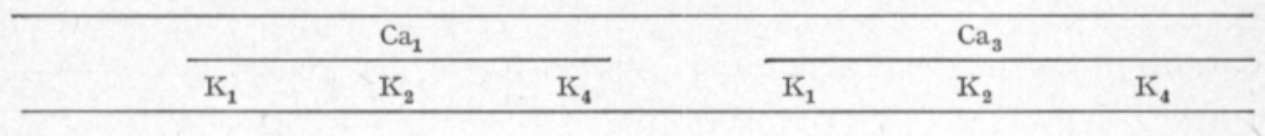

Grains

\begin{tabular}{rllllll}
\multicolumn{2}{c}{ 1st year } & & & & \\
$\mathrm{N}_{1} \mathrm{Mg}_{0}$ & $1.0^{\mathrm{b}}$ & $1.0^{\mathrm{b}}$ & $0.9^{\mathrm{a}}$ & $1.1^{\mathrm{e}}$ & $0.9^{\mathrm{a}}$ & $1.0^{\mathrm{b}}$ \\
$\mathrm{Mg}_{1}$ & $1.3^{\mathrm{e}}$ & $1.2^{\mathrm{d}}$ & $1.1^{\mathrm{e}}$ & $1.3^{\mathrm{e}}$ & $1.2^{\mathrm{d}}$ & $1.2^{\mathrm{d}}$ \\
$\mathrm{Mg}_{2}$ & $1.4^{\mathrm{f}}$ & $1.3^{\mathrm{e}}$ & $1.2^{\mathrm{d}}$ & $1.4^{\mathrm{f}}$ & $1.3^{\mathrm{e}}$ & $1.3^{\mathrm{e}}$ \\
$\mathrm{N}_{2} \mathrm{Mg}_{0}$ & $1.0^{\mathrm{b}}$ & $0.9^{\mathrm{a}}$ & $0.9^{\mathrm{a}}$ & $1.2^{\mathrm{d}}$ & $1.0^{\mathrm{b}}$ & $1.0^{\mathrm{b}}$ \\
$\mathrm{Mg}_{1}$ & $1.3^{\mathrm{e}}$ & $1.2^{\mathrm{d}}$ & $1.3^{\mathrm{e}}$ & $1.4^{\mathrm{t}}$ & $1.3^{\mathrm{e}}$ & $1.3^{\mathrm{e}}$ \\
$\mathrm{Mg}_{2}$ & $1.4^{\mathrm{f}}$ & $1.4^{\mathrm{f}}$ & $1.4^{\mathrm{f}}$ & $1.5^{\mathrm{g}}$ & $1.5^{\mathrm{g}}$ & $1.4^{\mathrm{f}}$
\end{tabular}

2nd year

$\begin{array}{rllllll}\mathrm{N}_{1} \mathrm{Mg}_{0} & 0.8^{\mathrm{abe}} & 0.7^{\mathrm{ab}} & 0.6^{\mathrm{a}} & 0.8^{\mathrm{abe}} & 0.8^{\mathrm{abe}} & 0.7^{\mathrm{ab}} \\ \mathrm{Mg}_{1} & 1.4^{\mathrm{gh}} & 1.3^{\text {fgh }} & 1.1^{\text {def }} & 1.2^{\text {efg }} & 1.2^{\text {efg }} & 1.1^{\text {def }} \\ \mathrm{Mg}_{2} & 1.6^{\mathrm{ij}} & 1.5^{\text {hij }} & 1.2^{\text {efg }} & 1.3^{\text {fgh }} & 1.2^{\text {efg }} & 1.1^{\text {def }} \\ \mathrm{N}_{2} \mathrm{Mg}_{0} & 0.9^{\text {bed }} & 1.0^{\text {ede }} & 0.7^{\mathrm{a}} & 1.1^{\text {def }} & 0.9^{\text {be }} & 0.9^{\text {be }} \\ \mathrm{Mg}_{1} & 1.4^{\mathrm{gh}} & 1.3^{\text {fgh }} & 1.2^{\text {efg }} & 1.4^{\mathrm{ghi}} & 1.3^{\mathrm{fgh}} & 1.2^{\text {efg }} \\ \mathrm{Mg}_{2} & 1.7^{\mathrm{j}} & 1.5^{\text {hij }} & 1.5^{\text {hij }} & 1.6^{\mathrm{jj}} & 1.3^{\mathrm{fgh}} & 1.4^{\mathrm{gh}}\end{array}$

$3 r d$ year

$\begin{array}{rllllll}\mathrm{N}_{1} \mathrm{Mg}_{0} & 0.9^{\mathrm{b}} & 0.9^{\mathrm{b}} & 0.7^{\mathrm{a}} & 1.1^{\mathrm{d}} & 1.0^{\mathrm{e}} & - \\ \mathrm{Mg}_{1} & 1.4^{\mathrm{g}} & 1.3^{\mathrm{f}} & 1.4^{\mathrm{g}} & 1.3^{\mathrm{f}} & 1.2^{\mathrm{e}} & 1.2^{\mathrm{e}} \\ \mathrm{Mg}_{2} & 1.6^{\mathrm{b}} & 1.5^{\mathrm{h}} & 1.7^{\mathrm{s}} & 1.4^{\mathrm{g}} & 1.4^{\mathrm{g}} & 1.3^{\mathrm{f}}\end{array}$

Straws

\begin{tabular}{|c|c|c|c|c|c|c|}
\hline $\mathrm{Mg}_{0}$ & $0.6^{\mathrm{abe}}$ & $0.6^{\mathrm{a}}$ & $0.4^{\mathrm{a}}$ & $0.8^{\mathrm{bc}}$ & $0.7^{\mathrm{abe}}$ & 0.7 abe \\
\hline $\mathrm{Mg}_{1}$ & $1.3 \mathrm{efgh}$ & $1.2^{\mathrm{defg}}$ & $0.9^{\mathrm{ed}}$ & $1.7^{1 \mathrm{jk}}$ & $1.7^{\mathrm{ijk}}$ & $1.4^{\mathrm{fghl}}$ \\
\hline $\mathrm{Mg}_{2}$ & $1.5 \mathrm{ghis}$ & $1.6^{\text {his }}$ & $1.2^{\text {defg }}$ & $2.1^{1 \mathrm{~m}}$ & $2.0^{\mathrm{klm}}$ & $1.8^{\mathrm{Jkl}}$ \\
\hline $\mathrm{Mg}_{0}$ & 0.7 abe & $0.6^{\mathrm{abc}}$ & $0.5^{\mathrm{ab}}$ & $1.2^{\mathrm{defg}}$ & $0.9^{\mathrm{ed}}$ & 0.7 abe \\
\hline $\mathrm{Mg}_{1}$ & $1.6^{\mathrm{h} 1 \mathrm{j}}$ & $1.7^{1 \mathrm{IJ}}$ & 1.3 etghi & $2.0^{\mathrm{k} 1 \mathrm{~m}}$ & $2.1^{1 \mathrm{~m}}$ & $1.8^{\mathrm{Jk} 1}$ \\
\hline $\mathrm{Mg}_{2}$ & $2.3^{\mathrm{mn}}$ & $2.3^{\mathrm{mn}}$ & $1.8^{\mathrm{Jk1}}$ & $2.70^{\circ}$ & $2.6^{\mathrm{no}}$ & $2.3^{\mathrm{mn}}$ \\
\hline
\end{tabular}

2nd year

\begin{tabular}{|c|c|c|c|c|c|c|}
\hline $\mathrm{N}_{1} \mathrm{Mg}_{0}$ & $0.4 \mathrm{abc}$ & $0.3^{\mathrm{ab}}$ & $0.2^{\mathrm{a}}$ & $0.3^{\mathrm{ab}}$ & $0.2^{\mathrm{a}}$ & $0.2^{\mathrm{a}}$ \\
\hline $\mathrm{Mg}_{1}$ & $1.6^{\text {hif }}$ & $1.2^{\mathrm{et}}$ & $0.6^{\mathrm{e}}$ & $2.0^{\mathrm{k} 1 \mathrm{~m}}$ & $1.8^{\mathrm{jk}}$ & $1.1^{\mathrm{e}}$ \\
\hline $\mathrm{Mg}_{2}$ & $2.2^{\mathrm{m}}$ & $1.8^{\mathrm{jk}}$ & $1.1^{\mathrm{e}}$ & $2.6^{\mathrm{n}}$ & $2.2^{\mathrm{m}}$ & $1.3^{\mathrm{efg}}$ \\
\hline $\mathrm{N}_{2} \mathrm{Mg}_{0}$ & $0.4^{\mathrm{abe}}$ & $0.5^{\mathrm{be}}$ & $0.5^{\mathrm{be}}$ & $0.8^{d}$ & $0.6^{\mathrm{ed}}$ & $0.5^{\mathrm{bc}}$ \\
\hline $\mathrm{Mg}_{1}$ & $1.4^{\mathrm{fgh}}$ & $1.2^{\mathrm{ef}}$ & $0.8^{d}$ & $2.2^{\mathrm{m}}$ & $1.4^{\mathrm{fgh}}$ & $1.3 \mathrm{efg}$ \\
\hline $\mathrm{Mg}_{2}$ & $2.1^{1 \mathrm{~m}}$ & $1.7^{11 \mathrm{~J}}$ & $1.5 \mathrm{ght}$ & $3.3^{\circ}$ & $2.0^{\mathrm{klm}}$ & $2.1^{1 \mathrm{~m}}$ \\
\hline
\end{tabular}

$\begin{array}{ccccccc}3 r d \text { year } & & & & & \\ \mathrm{N}_{1} \mathrm{Mg}_{0} & 0.5^{\mathrm{a}} & 0.5^{\mathrm{a}} & 0.4^{\mathrm{s}} & 0.5^{\mathrm{a}} & 0.5^{\mathrm{a}} & 0.3^{\mathrm{a}} \\ \mathrm{Mg}_{1} & 2.6^{\mathrm{d}} & 1.8^{\mathrm{c}} & 1.5^{\mathrm{bc}} & 2.7^{\mathrm{a}} & 2.0^{\mathrm{c}} & 1.1^{\mathrm{b}} \\ \mathrm{Mg}_{2} & 3.3^{\mathrm{et}} & 2.5^{\mathrm{d}} & 2.6^{\mathrm{d}} & 3.7^{\mathrm{f}} & 2.9^{\mathrm{de}} & 1.6^{\mathrm{bc}}\end{array}$

The results of the same year do not differ statistically sigcificantly if the same index letter appears. 
Grains obtained by an ample nitrogen fertilization have seldom a significantly higher magnesium content than by using a small rate of nitrogen. Doubling the nitrogen fertilization rate increased the magnesium content of the straws in the first year regardless of the rate of lime, and magnesium and potassium fertilization. An increase in the nitrogen fertilization rate did not any longer have a clear positive effect on the magnesium content of the second year straw yields as it had done in the first year.

\section{Potassium content of grains and straws}

The potassium content of the grains did not depend in the first year significantly on the studied variables (Table 2). The following year the potassium content of grains obtained without any magnesium fertilization and with an abundant nitrogen fertilization was higher than the potassium content of the other corresponding grains obtained by magnesium fertilization. The same was observed to be also true of the grains of the third year. An increase in the potassium rate increased the potassium content of the grains only when there was no magnesium fertilization.

The potassium content of the straws increased sharply as the rate of potassium fertilization was increased, and the increase was independent of the amount of lime, and magnesium and nitrogen fertilization. As was the case with the grains, the potassium content of the straws was also in the second year significantly higher with the high nitrogen rate than the potassium content of the straws obtained by magnesium fertilization.

Tripling the rate of lime depressed in the first year the potassium content of the straws. Doubling the nitrogen fertilization rate also affected negatively the potassium content of the straws, through only in the second year.

\section{Calcium content of grains and straws}

The calcium content of the grains was every year somewhat higher without magnesium fertilization than with magnesium (Table 3). The difference in the calcium contents was most pronounced with the abundant rate of lime application. Quadrupling the potassium rate depressed the calcium content of the grains in the first year at both levels of nitrogen fertilization and lime application, but in the second year only with the abundant lime rate.

Tripling the rate of lime application increased significantly the calcium content of the straws in the first year regardless of the rate of potassium, magnesium and nitrogen fertilization. In the third year increasing the rate of lime increased the calcium content of the straws only if there was no magnesium fertilization or a slight rate of potassium application.

The magnesium fertilization and a quadrupled potassium fertilization both depressed the calcium content of the straws regardless of the rates of liming and nitrogen fertilization. In all the years the calcium content of the straws was at its maximum when they had received no magnesium fertilization, but had received abundantly lime and nitrogen as well as a slight rate of potassium. 
Table 2. Potassium content of grains and straws $(\mathrm{K} / \mathrm{mg} / \mathrm{g}$ dry matter).

\begin{tabular}{cccccccc}
\hline \multicolumn{3}{c}{$\mathrm{Ca}_{1}$} & & \multicolumn{4}{c}{$\mathrm{Ca}_{3}$} \\
\cline { 2 - 5 } \cline { 5 - 7 } & $\mathrm{K}_{1}$ & $\mathrm{~K}_{2}$ & $\mathrm{~K}_{4}$ & & $\mathrm{~K}_{1}$ & $\mathrm{~K}_{2}$ & $\mathrm{~K}_{4}$ \\
\hline
\end{tabular}

Grains

\begin{tabular}{|c|c|c|c|c|c|c|}
\hline $\mathrm{N}_{1} \mathrm{Mg}_{0}$ & $5.4^{\mathrm{ab}}$ & $5.4^{\mathrm{ab}}$ & $5.6^{\mathrm{abed}}$ & 5.9 bede & 5.9bede & $5.4^{\mathrm{ab}}$ \\
\hline $\mathrm{Mg}_{1}$ & $5.3^{\mathrm{ab}}$ & $5.4^{\mathrm{ab}}$ & $5.7^{\mathrm{abed}}$ & $5.7^{\mathrm{abed}}$ & $5.4^{\mathrm{ab}}$ & $5.5^{\mathrm{abe}}$ \\
\hline $\mathrm{Mg}_{2}$ & $5.2^{\mathrm{a}}$ & $5.5^{\mathrm{abe}}$ & 5.7 abed & $5.4^{\mathrm{ab}}$ & $5.3^{\mathrm{ab}}$ & $5.5^{\mathrm{abe}}$ \\
\hline $\mathrm{N}_{2} \mathrm{Mg}_{0}$ & $5.8^{\text {abed }}$ & $5.9^{\text {bede }}$ & $6.1^{\text {ede }}$ & $6.4^{e}$ & $6.2^{\text {de }}$ & $6.2^{\text {de }}$ \\
\hline $\mathrm{Mg}_{1}$ & $5.5^{\mathrm{abe}}$ & 5.9 bede & $5.9^{\text {bede }}$ & $5.9^{\text {bede }}$ & 6.1 ede & 6.0 ede \\
\hline $\mathrm{Mg}_{2}$ & 5.8 abed & $5.5^{\mathrm{abe}}$ & $5.8^{\mathrm{abed}}$ & $5.6^{\mathrm{abed}}$ & $5.8^{\mathrm{abed}}$ & 6.1 ede \\
\hline
\end{tabular}

$$
2 \text { nd year }
$$

$\begin{array}{rllllll}\mathrm{N}_{1} \mathrm{Mg}_{0} & 6.9^{\mathrm{ab}} & 7.1^{\mathrm{abc}} & 7.5^{\mathrm{bc}} & 7.0^{\mathrm{abc}} & 6.9^{\mathrm{ab}} & 6.5^{\mathrm{ab}} \\ \mathrm{Mg}_{1} & 6.2^{\mathrm{ab}} & 6.7^{\mathrm{ab}} & 6.8^{\mathrm{ab}} & 6.0^{\mathrm{a}} & 6.0^{\mathrm{a}} & 6.2^{\mathrm{ab}} \\ \mathrm{Mg}_{2} & 6.3^{\mathrm{ab}} & 6.4^{\mathrm{ab}} & 6.6^{\mathrm{ab}} & 6.4^{\mathrm{ab}} & 5.7^{\mathrm{a}} & 6.1^{\mathrm{a}} \\ \mathrm{N}_{2} \mathrm{Mg}_{0} & 6.4^{\mathrm{ab}} & 8.4^{\mathrm{e}} & 13.1^{\mathrm{e}} & 9.2^{\mathrm{a}} & 14.2^{\mathrm{e}} & 9.7^{\mathrm{a}} \\ \mathrm{Mg}_{1} & 5.8^{\mathrm{a}} & 5.7^{\mathrm{a}} & 6.2^{\mathrm{ab}} & 5.8^{\mathrm{a}} & 6.2^{\mathrm{ab}} & 6.2^{\mathrm{ab}} \\ \mathrm{Mg}_{2} & 6.1^{\mathrm{a}} & 5.6^{\mathrm{a}} & 6.1^{\mathrm{a}} & 5.9^{\mathrm{a}} & 5.9^{\mathrm{a}} & 6.2^{\mathrm{ab}}\end{array}$

$$
\text { 3rd year }
$$

$\begin{array}{rllllll}\mathrm{N}_{1} \mathrm{Mg}_{0} & 6.9^{\mathrm{ab}} & 7.7^{\mathrm{bc}} & 8.6^{\mathrm{ed}} & 9.2^{\mathrm{a}} & 9.9^{\mathrm{a}} & - \\ \mathrm{Mg}_{1} & 6.8^{\mathrm{ab}} & 6.2^{\mathrm{a}} & 7.1^{\mathrm{ab}} & 6.6^{\mathrm{ab}} & 6.0^{\mathrm{a}} & 5.9^{\mathrm{a}} \\ \mathrm{Mg}_{2} & 7.1^{\mathrm{ab}} & 6.5^{\mathrm{ab}} & 7.4^{\mathrm{ab}} & 6.7^{\mathrm{ab}} & 6.4^{\mathrm{ab}} & 6.0^{\mathrm{a}}\end{array}$

\begin{tabular}{|c|c|c|c|}
\hline $\mathrm{N}_{1} \mathrm{Mg}_{0}$ & $4.8^{\mathrm{ab}}$ & $10.2^{\mathrm{fgh}}$ & $21.5^{1 \mathrm{~m}}$ \\
\hline $\mathrm{Mg}_{1}$ & $4.9^{\mathrm{ab}}$ & $9.5^{\mathrm{fg}}$ & $22.1^{m n}$ \\
\hline $\mathrm{Mg}_{2}$ & $4.4^{\mathrm{a}}$ & $10.5 \mathrm{gh}$ & $22.9^{\mathrm{n}}$ \\
\hline $\mathrm{N}_{2} \mathrm{Mg}_{0}$ & $5.6^{\mathrm{be}}$ & $9.9^{\mathrm{fgh}}$ & $18.0^{\mathrm{k}}$ \\
\hline $\mathrm{Mg}_{1}$ & $5.5^{\text {be }}$ & $11.4^{1}$ & $20.8^{1}$ \\
\hline $\mathrm{Mg}_{2}$ & $6.5^{\mathrm{ed}}$ & $11.5^{1}$ & $22.3^{\mathrm{mn}}$ \\
\hline
\end{tabular}

Straws

$\begin{array}{lcc}5.0^{\mathrm{ab}} & 8.4^{\mathrm{e}} & 18.2^{\mathrm{k}} \\ 4.1^{\mathrm{a}} & 9.7^{\mathrm{fgh}} & 17.7^{\mathrm{k}} \\ 4.6^{\mathrm{ab}} & 10.0^{\mathrm{fgh}} & 18.2^{\mathrm{k}} \\ & & \\ 7.3^{\mathrm{d}} & 10.6^{\mathrm{hi}} & 15.9^{\mathrm{f}} \\ 5.6^{\mathrm{b}} & 9.5^{\mathrm{fg}} & 17.5^{\mathrm{k}} \\ 6.2^{\mathrm{e}} & 9.3^{\mathrm{t}} & 15.0^{\mathrm{j}}\end{array}$

\begin{tabular}{|c|c|c|c|c|c|c|}
\hline $\mathrm{N}_{1} \mathrm{Mg}_{0}$ & $9.0^{\mathrm{abe}}$ & $15.3^{\text {ede }}$ & $39.8^{1}$ & $8.0^{\mathrm{abe}}$ & $12.3^{\mathrm{abc}}$ & $33.4^{\mathrm{hi}}$ \\
\hline $\mathrm{Mg}_{1}$ & $6.9 \mathrm{ab}$ & $14.2^{\text {ede }}$ & $32.7^{\mathrm{hi}}$ & $5.9^{\mathrm{a}}$ & $12.7 \mathrm{abed}$ & $30.2 \mathrm{~g}$ \\
\hline $\mathrm{Mg}_{2}$ & $5.8^{\mathrm{a}}$ & $15.0^{\text {ede }}$ & $33.9^{\mathrm{hi}}$ & $5.7 \mathrm{a}$ & $13.7^{\text {bed }}$ & $28.9 \mathrm{gh}$ \\
\hline $\mathrm{N}_{2} \mathrm{Mg}_{0}$ & $11.2^{\mathrm{abe}}$ & $24.7^{\mathrm{fg}}$ & $48.0^{\mathrm{J}}$ & 11. $3 \mathrm{abe}$ & 20.9 ef & $48.9^{J}$ \\
\hline $\mathrm{Mg}_{1}$ & $5.8^{\mathrm{a}}$ & $6.4^{\mathrm{ab}}$ & $19.4^{\text {def }}$ & $5.1^{\mathrm{a}}$ & $8.6^{\mathrm{abc}}$ & $20.9 \mathrm{ef}$ \\
\hline $\mathrm{Mg}_{2}$ & $4.8^{\mathrm{a}}$ & $8.7^{a b c}$ & $22.1^{\text {ef }}$ & $5.3^{\mathrm{a}}$ & $9.8^{a b c}$ & $20.9^{\mathrm{et}}$ \\
\hline
\end{tabular}

2nd year

3rd year

\begin{tabular}{rrlllll}
$\mathrm{N}_{1} \mathrm{Mg}_{0}$ & $15.7^{\mathrm{a}}$ & $36.4^{\mathrm{abed}}$ & $48.5^{\mathrm{bed}}$ & $19.8^{\mathrm{a}}$ & $63.5^{\mathrm{d}}$ & $65.2^{\mathrm{d}}$ \\
$\mathrm{Mg}_{1}$ & $11.3^{\mathrm{a}}$ & $20.9^{\mathrm{ab}}$ & $53.0^{\mathrm{ed}}$ & $15.8^{\mathrm{a}}$ & $27.2^{\mathrm{abe}}$ & $52.3^{\text {be }}$ \\
$\mathrm{Mg}_{2}$ & $9.9^{\mathrm{a}}$ & $20.4^{\mathrm{a}}$ & $51.6^{\mathrm{bed}}$ & $15.1^{\mathrm{a}}$ & $27.4^{\mathrm{abe}}$ & $59.5^{\mathrm{d}}$ \\
\hline
\end{tabular}

Meaning of index letters same as in Table 1. 
Table 3. Calcium content of grains and straws (Ca mg/g dry matter).

\begin{tabular}{cccccccc}
\hline \multicolumn{3}{c}{$\mathrm{Ca}_{1}$} & & \multicolumn{3}{c}{$\mathrm{Ca}_{3}$} \\
\cline { 2 - 5 } \cline { 5 - 7 } & $\mathrm{K}_{2}$ & & $\mathrm{~K}_{4}$ & & $\mathrm{~K}_{1}$ & $\mathrm{~K}_{2}$ & $\mathrm{~K}_{4}$ \\
\hline
\end{tabular}

Grains

\begin{tabular}{cllllll} 
1st year & \multicolumn{1}{c}{} & & \\
$\mathrm{N}_{1} \mathrm{Mg}_{0}$ & $2.0^{\mathrm{de}}$ & $1.9^{\mathrm{de}}$ & $1.4^{\mathrm{ab}}$ & $2.0^{\mathrm{de}}$ & $1.7^{\mathrm{ed}}$ & $1.4^{\mathrm{ab}}$ \\
$\mathrm{Mg}_{1}$ & $1.7^{\mathrm{ed}}$ & $1.5^{\mathrm{abe}}$ & $1.3^{\mathrm{a}}$ & $1.7^{\mathrm{ed}}$ & $1.5^{\mathrm{abe}}$ & $1.3^{\mathrm{a}}$ \\
$\mathrm{Mg}_{2}$ & $1.7^{\mathrm{ed}}$ & $1.4^{\mathrm{ab}}$ & $1.2^{\mathrm{a}}$ & $1.8^{\mathrm{ed}}$ & $1.4^{\mathrm{ab}}$ & $1.2^{\mathrm{a}}$ \\
$\mathrm{N}_{2} \mathrm{Mg}_{0}$ & $2.0^{\mathrm{de}}$ & $1.8^{\mathrm{ed}}$ & $1.5^{\mathrm{abe}}$ & $2.2^{\mathrm{e}}$ & $2.0^{\mathrm{de}}$ & $1.8^{\mathrm{ed}}$ \\
$\mathrm{Mg}_{1}$ & $1.9^{\mathrm{de}}$ & $1.5^{\mathrm{abe}}$ & $1.3^{\mathrm{a}}$ & $2.1^{\mathrm{e}}$ & $1.6^{\mathrm{be}}$ & $1.4^{\mathrm{ab}}$ \\
$\mathrm{Mg}_{2}$ & $1.7^{\mathrm{e}}$ & $1.4^{\mathrm{ab}}$ & $1.2^{\mathrm{a}}$ & $2.1^{\mathrm{e}}$ & $1.6^{\mathrm{be}}$ & $1.4^{\mathrm{a}}$
\end{tabular}

2nd year

$\begin{array}{rllllll}\mathrm{N}_{1} \mathrm{Mg}_{0} & 1.0^{\mathrm{bc}} & 1.1^{\mathrm{c}} & 0.8^{\mathrm{ab}} & 1.2^{\mathrm{c}} & 1.0^{\mathrm{bc}} & 0.8^{\mathrm{ab}} \\ \mathrm{Mg}_{1} & 0.8^{\mathrm{abc}} & 0.8^{\mathrm{ab}} & 0.7^{\mathrm{ab}} & 0.9^{\mathrm{abc}} & 0.8^{\mathrm{ab}} & 0.6^{\mathrm{a}} \\ \mathrm{Mg}_{2} & 0.8^{\mathrm{ab}} & 0.8^{\mathrm{ab}} & 0.6^{\mathrm{ab}} & 1.0^{\mathrm{be}} & 0.7^{\mathrm{ab}} & 0.6^{\mathrm{a}} \\ \mathrm{N}_{2} \mathrm{Mg}_{0} & 1.0^{\mathrm{bc}} & 1.0^{\mathrm{bc}} & 1.9^{\mathrm{d}} & 2.4^{\mathrm{e}} & 2.6^{\mathrm{e}} & 1.7^{\mathrm{a}} \\ \mathrm{Mg}_{1} & 1.0^{\mathrm{bc}} & 0.9^{\mathrm{abc}} & 0.7^{\mathrm{ab}} & 1.1^{\mathrm{c}} & 1.0^{\mathrm{bc}} & 0.8^{\mathrm{ab}} \\ \mathrm{Mg}_{2} & 1.0^{\mathrm{bc}} & 0.7^{\mathrm{ab}} & 0.7^{\mathrm{ab}} & 1.3^{\mathrm{c}} & 0.9^{\mathrm{abc}} & 0.7^{\mathrm{ab}}\end{array}$

3rd year

$\begin{array}{rllllll}\mathrm{N}_{1} \mathrm{Mg}_{0} & 0.8^{\mathrm{a}} & 1.0^{\mathrm{a}} & 2.4^{\mathrm{a}} & 5.9^{\mathrm{b}} & 2.2^{\mathrm{a}} & - \\ \mathrm{Mg}_{1} & 0.8^{\mathrm{a}} & 0.8^{\mathrm{a}} & 1.0^{\mathrm{a}} & 1.0^{\mathrm{a}} & 0.8^{\mathrm{a}} & 0.8^{\mathrm{a}} \\ \mathrm{Mg}_{2} & 0.9^{\mathrm{a}} & 0.9^{\mathrm{a}} & 1.2^{\mathrm{a}} & 1.0^{\mathrm{a}} & 0.9^{\mathrm{a}} & 0.7^{\mathrm{a}}\end{array}$

Straws

\begin{tabular}{|c|c|c|c|c|c|c|}
\hline $\mathrm{Mg}_{0}$ & 13. $2^{\text {edefghi }}$ & 11.4abedef & $8.7 \mathrm{ab}$ & $20.2^{\mathrm{k} \operatorname{lm}}$ & $15.5^{\text {fghis }}$ & 11.1 abedet \\
\hline $\mathrm{Mg}_{1}$ & $12.5^{\text {bedefgh }}$ & $10.4^{\text {abede }}$ & $7.7^{\mathrm{a}}$ & $16.4 \mathrm{ghijk}$ & $14.5^{\text {efghi }}$ & 11. $3^{\text {abedef }}$ \\
\hline $\mathrm{Mg}_{2}$ & $11.4^{\mathrm{ab}} \mathrm{cde}$ & $9.4^{\mathrm{abed}}$ & $8.5^{\mathrm{ab}}$ & $16.5^{\mathrm{ghijk}}$ & 13. $4_{\text {defght }}$ & 11.1 abedef \\
\hline $\mathrm{Mg}_{0}$ & $17.0^{\mathrm{hijk1}}$ & 16.6ghijk1 & $12.2^{\mathrm{abedefg}}$ & $28.8^{\mathrm{n}}$ & $23.4 \mathrm{mn}$ & $17.6^{1 \mathrm{Jk} 1}$ \\
\hline $\mathrm{Mg}_{1}$ & $17.6^{1 \mathrm{jk} 1}$ & $16.4 \mathrm{ghijk1}$ & 11. $2^{\mathrm{abede}}$ & $24.7^{m n}$ & $21.1^{1 \mathrm{~m}}$ & $15.5^{\text {fghis }}$ \\
\hline $\mathrm{Mg}_{2}$ & $17.3^{i j k 1}$ & 14.9 efghis & 11.2 $2^{\text {abedef }}$ & $27.3^{n}$ & $19.2^{j \mathrm{kl}}$ & 14.5 efgh1 \\
\hline
\end{tabular}

2nd year

\begin{tabular}{|c|c|c|c|c|c|c|c|}
\hline \multirow[t]{3}{*}{$\mathrm{N}_{1}$} & $\mathrm{Mg}_{0}$ & $8.8^{\text {efgh }}$ & $6.4^{\mathrm{bed}}$ & $5.0^{\mathrm{a}}$ & $13.6^{\mathrm{J}}$ & $9.5^{\mathrm{hi}}$ & 5.9abed \\
\hline & $\mathrm{Mg}_{1}$ & $6.9^{\text {bede }}$ & $5.0^{\mathrm{abc}}$ & $3.6^{\mathrm{a}}$ & $10.3^{\mathrm{hI}}$ & $7.8^{\text {defg }}$ & $5.0^{\mathrm{abe}}$ \\
\hline & $\mathrm{Mg}_{2}$ & $6.5^{\text {bede }}$ & $5.2^{\mathrm{abc}}$ & $3.6^{\mathrm{a}}$ & $9.3^{\mathrm{tg}}$ & $7.0^{\text {edef }}$ & $5.0^{\mathrm{abc}}$ \\
\hline \multirow[t]{4}{*}{$\mathrm{N}_{2}$} & $\mathrm{Mg}_{0}$ & $7.8^{\text {defg }}$ & 8.1 detgh & $7.1^{\text {edet }}$ & $28.1^{\mathrm{m}}$ & $23.6^{1}$ & $11.1^{1}$ \\
\hline & $\mathrm{Mg}_{1}$ & $7.0^{\text {edet }}$ & $6.2^{\mathrm{abed}}$ & $4.2^{\mathrm{ab}}$ & $15.3^{\mathrm{jk}}$ & $10.9^{\text {hi }}$ & 7.5 defg \\
\hline & $\mathrm{Mg}_{2}$ & $7.2^{\text {edef }}$ & 5.9 abed & $4.8^{\mathrm{abc}}$ & $17.1^{\mathrm{k}}$ & $10.6^{\mathrm{hl}}$ & $7.6^{\mathrm{defg}}$ \\
\hline & $3 r d$, & & & & & & \\
\hline \multirow[t]{3}{*}{$\mathrm{N}_{1}$} & $\mathrm{Mg}_{0}$ & $8.1^{\mathrm{a}}$ & $7.5^{\mathrm{a}}$ & $6.6^{\mathrm{a}}$ & $26.9^{d}$ & $19.5^{\mathrm{e}}$ & $14.7^{b}$ \\
\hline & $\mathrm{Mg}_{1}$ & $6.6^{\mathrm{a}}$ & $5.3^{\mathrm{a}}$ & $5.1^{\mathrm{s}}$ & $12.7^{b}$ & $7.4^{\mathrm{a}}$ & $5.0^{\mathrm{a}}$ \\
\hline & $\mathrm{Mg}_{2}$ & $5.8^{\mathrm{a}}$ & $4.5^{\mathrm{a}}$ & $5.7^{\mathrm{a}}$ & $11.8^{b}$ & $7.5^{\mathrm{a}}$ & $5.0^{\mathrm{a}}$ \\
\hline
\end{tabular}

Meaning of index letters same as in Table 1. 
Table 4. Nitrogen content of grains and straws ( $\mathrm{N} \mathrm{mg/g} \mathrm{dry} \mathrm{matter).}$

\begin{tabular}{ccccccc}
\hline & \multicolumn{3}{c}{$\mathrm{Ca}_{3}$} & & \multicolumn{3}{c}{$\mathrm{Ca}_{3}$} \\
\cline { 2 - 7 } \cline { 5 - 7 } & $\mathrm{K}_{2}$ & $\mathrm{~K}_{4}$ & & $\mathrm{~K}_{1}$ & $\mathrm{~K}_{2}$ & $\mathrm{~K}_{4}$ \\
\hline
\end{tabular}

Grains

1 st year $\mathrm{Mg}_{1}$

$16.8^{\mathrm{ab}}$

$14.8^{\mathrm{a}}$

$14.8^{\mathrm{a}}$

$15.7^{\mathrm{ab}}$

$13.7^{\mathrm{a}}$

$14.0^{\mathrm{a}}$

$\mathrm{Mg}_{2}$

$16.4^{\mathrm{ab}}$

$13.8^{\mathrm{a}}$

$14.7 \mathrm{a}$

$15.2^{\mathrm{a}}$

$14.4^{\mathrm{a}}$

$14.0^{\mathrm{a}}$

$\mathrm{N}_{2} \mathrm{Mg}_{0}$

$24.5^{\text {de }}$

$20.5^{\text {bed }}$

22.2ede

$16.5^{\mathrm{ab}}$

$15.9^{\mathrm{ab}}$

$13.7^{\mathrm{a}}$

$\mathrm{Mg}_{1}$

$29.2^{\text {tg }}$

$24.3^{\text {de }}$

$31.9 \mathrm{~g}$

23.6 ede

19.3 be

$29.4^{\mathrm{fg}}$

23.6 ede

20.3 bed

$\mathrm{Mg}_{2}$

$31.2 \mathrm{~g}$

$26.5^{\text {ef }}$

$25.5^{\text {et }}$

$30.3 \mathrm{~g}$

$23.9^{\text {ede }}$

$20.3^{\text {bed }}$

\begin{tabular}{|c|c|}
\hline \multicolumn{2}{|c|}{ 2nd year } \\
\hline $\mathrm{Mg}_{0}$ & $23.1^{\mathrm{ab}}$ \\
\hline $\mathrm{Mg}_{1}$ & $17.0^{\mathrm{ab}}$ \\
\hline $\mathrm{Mg}_{2}$ & $16.5^{\mathrm{ab}}$ \\
\hline $\mathbf{M g}_{0}$ & $33.7^{\mathrm{be}}$ \\
\hline $\mathrm{Mg}_{1}$ & $30.6^{b}$ \\
\hline $\mathrm{Mg}_{2}$ & $30.6^{\mathrm{b}}$ \\
\hline $3 r d$ & \\
\hline $\mathrm{Mg}_{0}$ & $42.8^{\mathrm{e}}$ \\
\hline $\mathrm{Mg}_{1}$ & $27.6^{\mathrm{ed}}$ \\
\hline $\mathrm{Mg}_{2}$ & $24.7^{\mathrm{bc}}$ \\
\hline
\end{tabular}

$\begin{array}{ll}17.0^{\mathrm{ab}} & 19.2^{\mathrm{ab}} \\ 15.9^{\mathrm{ab}} & 17.0^{\mathrm{ab}} \\ 17.3^{\mathrm{ab}} & 18.6^{\mathrm{ab}} \\ 31.4^{\mathrm{bc}} & - \\ 23.3^{\mathrm{ab}} & 24.0^{\mathrm{ab}} \\ 24.0^{\mathrm{ab}} & 25.0^{\mathrm{ab}}\end{array}$

17. $3 \mathrm{ab}$

$15.7^{\mathrm{ab}}$

$14.5^{\mathrm{a}}$

$15.4^{\mathrm{ab}}$

$14.8^{\mathrm{a}}$

$14.1^{\mathrm{a}}$

$15.3^{\mathrm{ab}}$

$15.0^{\mathrm{a}}$

$13.4^{\mathrm{a}}$

$45.1^{\circ}$

$43.5^{\circ}$

$25.6^{\mathrm{ab}}$

$20.9^{\mathrm{ab}}$

21. $2^{\mathrm{ab}}$

$28.5^{\mathrm{b}}$

$23.9^{\mathrm{ab}}$

$22.0^{\mathrm{ab}}$

\section{Straws}

$$
1 \text { st year }
$$

$\mathrm{N}_{1} \mathrm{Mg}_{0}$

$5.8^{\text {bed }}$

21. $6^{\mathrm{ab}}$

$25.2^{\mathrm{bc}}$

${ }^{-}{ }^{\mathrm{d}}$

$25.9^{\mathrm{e}}$

$27.8 \mathrm{ed}$

$\overline{20.3 \mathrm{a}}$

$\overline{19.9 \mathrm{a}}$

$\overline{21.2 \mathrm{ab}}$

$19.7^{\mathrm{a}}$

$20.3^{\mathrm{a}}$

$21.3^{\mathrm{ab}}$

$\mathrm{Mg}_{1}$

5.3 3 bed

4.9 abe

5. $6^{\text {bed }}$

$\mathrm{Mg}_{2}$

$5.7^{\text {bed }}$

$4.1^{\mathrm{ab}}$

$4.5^{\mathrm{ab}}$

$4.3^{\mathrm{ab}}$

$\mathrm{N}_{2} \mathrm{Mg}_{0}$

$12.0 \mathrm{~g}$

4.7 abe

$6.5^{\text {ede }}$

$7.2^{\text {de }}$

$7.2^{\text {de }}$

$\mathrm{Mg}_{2}$

$12.3 \mathrm{~g}$

$8.3^{\text {et }}$

$7.1^{\text {de }}$

$5.6^{\text {bed }}$
$5.8^{\text {bed }}$
$4.9^{\mathrm{abe}}$

$4.4^{\mathrm{ab}}$

$3.5^{\mathrm{a}}$

$3.9^{\mathrm{ab}}$

$3.1^{\mathrm{a}}$

$3.9^{\mathrm{ab}}$

$3.4^{\mathrm{a}}$

$8.2^{\text {et }}$

$15.1^{\mathrm{h}}$

$9.8^{t}$

6.6 ede

$13.8^{\mathrm{gh}}$

$7.6^{\mathrm{de}}$

$5.7^{\mathrm{bed}}$

$13.6 \mathrm{gh}$

7.9e?

$5.6^{\mathrm{bed}}$

$\begin{array}{rrrr}2 \text { 2ad year } & & & \\ \mathrm{N}_{1} \mathrm{Mg}_{0} & 11.2^{\mathrm{ed}} & 6.7^{\mathrm{ab}} & 7.0^{\mathrm{ab}} \\ \mathrm{Mg}_{1} & 7.4^{\mathrm{ab}} & 5.9^{\mathrm{ab}} & 5.0^{\mathrm{ab}} \\ \mathrm{Mg}_{2} & 6.9^{\mathrm{ab}} & 5.7^{\mathrm{ab}} & 4.5^{\mathrm{ab}} \\ & & & \\ \mathrm{N}_{2} \mathrm{Mg}_{0} & 22.5^{\mathrm{e}} & 31.8^{\mathrm{f}} & 32.8^{\mathrm{f}} \\ \mathrm{Mg}_{1} & 13.3^{\mathrm{d}} & 7.3^{\mathrm{ab}} & 6.7^{\mathrm{ab}} \\ \mathrm{Mg}_{2} & 12.6^{\mathrm{d}} & 7.8^{\mathrm{ab}} & 7.6^{\mathrm{ab}}\end{array}$

$6.7^{\mathrm{ab}}$
$6.0^{\mathrm{ab}}$
$5.6^{\mathrm{ab}}$

$30.8^{\mathrm{P}}$

$12.4^{\text {ed }}$

$11.8^{\mathrm{ed}}$

$21.4^{\mathrm{d}}$
$9.4^{\mathrm{abe}}$
$9.0^{\mathrm{abe}}$

30.6

$5.7 \mathrm{a}$

$10.5^{\text {abe }} \quad 12.9^{\mathrm{c}}$

$9.5 \mathrm{abe}$

$14.6^{\mathrm{c}}$

$6.8^{\mathrm{ab}}$

$5.4^{\mathrm{ab}}$

$4.8^{\mathrm{a}}$

$4.3^{\mathrm{ab}}$

$3.9^{\mathrm{a}}$

$4.3 \mathrm{ab}$

$38.3 \mathrm{~g}$

$7.1^{\mathrm{ab}}$

$7.3^{\mathrm{ab}}$

$6.0^{\mathrm{ab}}$

Meaning of index letters same as in Table 1. 
The effect of the magnesium fertilization on the nitrogen content of the grains was slight during the whole experiment at all the rates of potassium and nitrogen fertilization and at all the rates of lime application (Table 4). Exceptions were the increase, caused by the magnesium fertilization, in the nitrogen content in the first year in the grains, and the depression of the nitrogen content in the second and the third years. Doubling the rate of nitrogen fertilization increased significantly the nitrogen content of the grains of the first year regardless of the rate of magnesium and potassium fertilization and the rate of lime application.

The plants which had received an abundant nitrogen and potassium fertilization developed in the second year so few grains that there was not enough for nitrogen content determinations. In the third year it was possible to determine the nitrogen content of the grains at the two smallest rates of potassium application at the level of low lime application.

The nitrogen content of the straws decreased as the rate of potassium fertilization was increased. In all the years the differences were the most pronounced for the yields which had received a magnesium fertilization as well as abundant nitrogen fertilization and liming. Without the magnesium fertilization the straws contained in the second year more nitrogen with an abundant rate of nitrogen application than the yields that had been obtained by using magnesium fertilization.

\section{Interdependence of cation contents in grains and straws}

In the grains there was between the magnesium and calcium content or the magnesium and potassium content no significant correlation. In the straws the magnesium content was depressed as the potassium content increased. Within the data of this experiment the correlation coefficients between the cation contents were as follows:

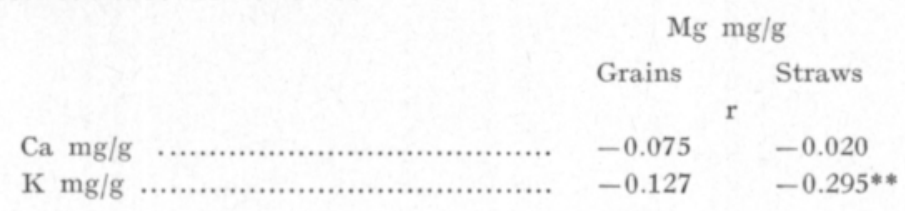

Potassium to magnesium ratio $(K / M g)$ in grains and straws

In all the years the annually renewed magnesium fertilization decreased the ratio $\mathrm{K} / \mathrm{Mg}$ in grains (Table 5). The two rates of magnesium application showed no difference in this respect. An inrease in the rate of potassium fertilization increased the ratio only in the grains obtained without magnesium fertilization.

In the straws the ratio $\mathrm{K} / \mathrm{Mg}$ likewise decreased significantly every year as a result of the magnesium fertilization. An increase in the rate of potassium application increased the ratio $\mathrm{K} / \mathrm{Mg}$ very clearly without the magnesium fertilization. The increase in the value of the ratio was greater at the low level of nitrogen application than at the high level of nitrogen application. Tripling the rate of lime application decreased the ratio $\mathrm{K} / \mathrm{Mg}$ at the highest rate of 
potassium fertilization irrespective of the rate of magnesium in the first year. In the following years an increase in the rate of lime application at the low rate of nitrogen and the highest rate of potassium application increased the ratio.

An increase in the ratio of potassium to magnesium in fertilization, increased significantly the ratio of the same cations in the grains and the straws. In all the data from the three years the results were as follows:

\begin{tabular}{|c|c|c|c|c|c|}
\hline & \multicolumn{4}{|c|}{$\mathrm{K} / \mathrm{Mg}$ in fertilization } \\
\hline & & 0.32 & 0.65 & 1.29 & 2.58 \\
\hline & & \multicolumn{4}{|c|}{$\mathrm{K} / \mathrm{Mg}$ in yields } \\
\hline Grains & & $1.3^{\mathrm{a}}$ & $1.4^{\mathrm{b}}$ & $1.5^{\mathrm{e}}$ & $1.6^{\mathrm{d}}$ \\
\hline Straws & ....... & $0.8^{\mathrm{a}}$ & $1.6^{\mathrm{b}}$ & $4.1^{\circ}$ & $8.3^{\mathrm{d}}$ \\
\hline
\end{tabular}

The increase in the ratio $\mathrm{K} / \mathrm{Mg}$ was greater in the straws than in the grains. The two rates of magnesium or the three of potassium fertilization both altered the potassium to magnesium ratio in the yields less than the cation ratios in the fertilization.

Ratio of potassium to the sum of calcium and magnesium $(K /(C a+M g))$ in grains and straws

The magnesium fertilization depressed in the second and the third years the ratio $\mathrm{K} /(\mathrm{Ca}+\mathrm{Mg})$ in the grains irrespective of the rate of nitrogen and potassium fertilization and the rate of liming (Table 6). The two rates of magnesium application did not show a significant difference in the results. Neither an increase in the rate of liming nor one in nitrogen fertilization produced an effect on the ratio in the grains. The increase in the ratio caused by quadrupling the rate of potassium fertilization in grains produced without magnesium fertilization was significant from the second year on.

Upon increasing the rate of potassium fertilization the ratio $\mathrm{K} /(\mathrm{Ca}+\mathrm{Mg})$ in the straws increased every year. The increase in the ratio caused by potassium fertilization was smaller at the rate of tripled lime application than at the rate of slight lime application. Also, doubling the rate of nitrogen fertilization retarded the increase of the ratio in the first two years.

\section{Magnesium uptake}

The amount of magnesium taken up by the grains depended more clearly on the amount of the yield than on the magnesium content. With the straws, on the other hand, the significance of the magnesium content was greater than that of the yield. The changes in the amount of magnesium taken up by the whole yield followed the changes in the uptake of magnesium by the straws.

The amount of magnesium taken up by the grains and the straws increased significantly every year upon increasing the rate of magnesium fertilization, and independent of other tested nutrients (Table 7). Only in the third year did the yields which had received small amounts of calcium and the two greatest rates of potassium take up equal amounts of magnesium when using two different rates of magnesium fertilizer. 
Table 5. Potassium to magnesium ratio $(\mathrm{K} / \mathrm{Mg})$ in grains and straws.

\begin{tabular}{cccccccc}
\hline \multicolumn{3}{c}{$\mathrm{Ca}_{1}$} & & \multicolumn{3}{c}{$\mathrm{Ca}_{3}$} \\
\cline { 2 - 3 } \cline { 5 - 7 } & $\mathrm{K}_{1}$ & $\mathrm{~K}_{4}$ & & $\mathrm{~K}_{1}$ & $\mathrm{~K}_{2}$ & $\mathrm{~K}_{4}$ \\
\hline
\end{tabular}

Grains

\begin{tabular}{|c|c|c|c|c|c|c|}
\hline $\mathrm{N}_{1} \mathrm{Mg}_{0}$ & 1.7 ede & $1.8^{\text {def }}$ & $1.9 \mathrm{efg}$ & $1.7^{\text {ede }}$ & $2.0^{\mathrm{fg}}$ & $1.8^{\text {def }}$ \\
\hline $\mathrm{Mg}_{1}$ & $1.3^{\mathrm{ab}}$ & $1.4^{\mathrm{ab}}$ & $1.6^{\mathrm{ed}}$ & $1.4^{\mathrm{ab}}$ & $1.4^{\mathrm{ab}}$ & $1.4^{\mathrm{ab}}$ \\
\hline $\mathrm{Mg}_{2}$ & $1.2^{\mathrm{a}}$ & $1.3^{\mathrm{ab}}$ & $1.5^{\mathrm{be}}$ & $1.2^{\mathrm{a}}$ & $1.3^{\mathrm{ab}}$ & $1.5^{\text {be }}$ \\
\hline $\mathrm{N}_{2} \mathrm{Mg}_{0}$ & $1.8^{\text {det }}$ & $2.0^{\mathrm{fg}}$ & $2.1 \mathrm{~g}$ & $1.8^{\text {def }}$ & $1.9 \mathrm{efg}$ & $2.1 \mathrm{~g}$ \\
\hline $\mathrm{Mg}_{1}$ & $1.3^{\mathrm{ab}}$ & $1.5^{\mathrm{be}}$ & $1.5^{\mathrm{bc}}$ & $1.3^{\mathrm{ab}}$ & $1.5^{\mathrm{bc}}$ & $1.4^{\mathrm{ab}}$ \\
\hline $\mathrm{Mg}_{2}$ & $1.3^{\mathrm{ab}}$ & $1.2^{\mathrm{a}}$ & $1.3^{\mathrm{ab}}$ & $1.2^{\mathrm{a}}$ & $1.2^{\mathrm{a}}$ & $1.3^{\mathrm{a}}$ \\
\hline
\end{tabular}

$2 n d$ year

$\begin{array}{rllllll}\mathrm{N}_{1} \mathrm{Mg}_{0} & 2.6^{\mathrm{b}} & 3.3^{\mathrm{ed}} & 3.7^{\mathrm{a}} & 2.8^{\mathrm{bc}} & 2.8^{\mathrm{be}} & 3.0^{\mathrm{be}} \\ \mathrm{Mg}_{1} & 1.4^{\mathrm{a}} & 1.7^{\mathrm{a}} & 2.0^{\mathrm{a}} & 1.5^{\mathrm{a}} & 1.6^{\mathrm{a}} & 1.8^{\mathrm{a}} \\ \mathrm{Mg}_{2} & 1.2^{\mathrm{a}} & 1.4^{\mathrm{a}} & 1.7^{\mathrm{a}} & 1.5^{\mathrm{a}} & 1.4^{\mathrm{a}} & 1.7^{\mathrm{a}} \\ \mathrm{N}_{2} \mathrm{Mg}_{0} & 2.3^{\mathrm{b}} & 2.9^{\mathrm{bc}} & 5.9^{\mathrm{f}} & 2.6^{\mathrm{b}} & 5.0^{\mathrm{e}} & 3.4^{\mathrm{cd}} \\ \mathrm{Mg}_{1} & 1.3^{\mathrm{a}} & 1.4^{\mathrm{a}} & 1.6^{\mathrm{a}} & 1.3^{\mathrm{a}} & 1.5^{\mathrm{a}} & 1.6^{\mathrm{a}} \\ \mathrm{Mg}_{2} & 1.2^{\mathrm{a}} & 1.2^{\mathrm{a}} & 1.3^{\mathrm{a}} & 1.2^{\mathrm{a}} & 1.4^{\mathrm{a}} & 1.4^{\mathrm{a}}\end{array}$

$3 r d$ year

$\begin{array}{rllllll}\mathrm{N}_{1} \mathrm{Mg}_{0} & 2.4^{\mathrm{b}} & 2.8^{\mathrm{b}} & 3.8^{\mathrm{e}} & 2.9^{\mathrm{b}} & 1.6^{\mathrm{a}} & - \\ \mathrm{Mg}_{1} & 1.5^{\mathrm{a}} & 1.5^{\mathrm{a}} & 1.6^{\mathrm{a}} & 1.7^{\mathrm{a}} & 1.5^{\mathrm{a}} & 1.6^{\mathrm{a}} \\ \mathrm{Mg}_{2} & 1.4^{\mathrm{a}} & 1.3^{\mathrm{a}} & 1.4^{\mathrm{a}} & 1.5^{\mathrm{a}} & 1.5^{\mathrm{a}} & 1.5^{\mathrm{a}}\end{array}$

\section{Straws}

\begin{tabular}{|c|c|c|c|c|c|c|}
\hline $\mathrm{N}_{1} \mathrm{Mg}_{0}$ & $2.5^{\mathrm{ed}}$ & $5.2^{t}$ & $15.9^{k}$ & $2.0^{\circ}$ & $3.6^{\mathrm{e}}$ & $8.2^{1}$ \\
\hline $\mathrm{Mg}_{1}$ & $1.2^{\mathrm{ab}}$ & $2.5^{\mathrm{ed}}$ & $8.0^{\mathrm{h} 1}$ & $0.8^{\mathrm{a}}$ & $1.7^{\mathrm{be}}$ & $4.0^{\mathrm{e}}$ \\
\hline $\mathrm{Mg}_{2}$ & $0.9^{\mathrm{ab}}$ & $2.0^{\mathrm{c}}$ & $6.0 \mathrm{~g}$ & $0.7^{\mathrm{a}}$ & $1.5^{\mathrm{abe}}$ & $3.2^{\mathrm{d}}$ \\
\hline $\mathrm{N}_{2} \mathrm{Mg}_{0}$ & $2.4^{\mathrm{c}}$ & $5.0^{f}$ & $11.8^{\mathrm{J}}$ & $1.9^{\circ}$ & $3.7^{e}$ & $7.3^{\mathrm{h}}$ \\
\hline $\mathrm{Mg}_{1}$ & $1.1^{\mathrm{ab}}$ & $2.1^{\mathrm{c}}$ & $5.1^{t}$ & $0.9^{\mathrm{ab}}$ & $1.4^{\mathrm{abe}}$ & $3.0^{d}$ \\
\hline $\mathrm{Mg}_{2}$ & $0.9 \mathrm{ab}$ & $1.6^{\mathrm{be}}$ & $3.8^{\mathrm{e}}$ & $0.7 \mathrm{a}$ & $1.1 \mathrm{ab}$ & $2.1^{\mathrm{e}}$ \\
\hline
\end{tabular}

\section{2nd year}

$\begin{array}{rlccccc}\mathrm{N}_{1} \mathrm{Mg}_{0} & 7.9^{\text {defg }} & 15.0^{\mathrm{h}} & 37.5^{\mathrm{j}} & 9.3^{\mathrm{fg}} & 16.2^{\mathrm{h}} & 53.9^{\mathrm{k}} \\ \mathrm{Mg}_{1} & 1.4^{\mathrm{ab}} & 3.8^{\mathrm{abede}} & 16.1^{\mathrm{h}} & 0.9^{\mathrm{ab}} & 2.3^{\mathrm{abede}} & 8.7^{\mathrm{fg}} \\ \mathrm{Mg}_{2} & 0.8^{\mathrm{a}} & 2.6^{\mathrm{abede}} & 9.3^{\mathrm{fg}} & 0.7^{\mathrm{a}} & 2.0^{\mathrm{abed}} & 6.8^{\text {bedef }} \\ \mathrm{N}_{2} \mathrm{Mg}_{0} & 8.2^{\mathrm{efg}} & 15.8^{\mathrm{h}} & 30.4^{1} & 4.2^{\mathrm{abedef}} & 13.6^{\mathrm{gh}} & 30.0^{1} \\ \mathrm{Mg}_{1} & 1.3^{\mathrm{ab}} & 1.7^{\mathrm{abe}} & 7.5^{\mathrm{edef}} & 0.7^{\mathrm{a}} & 1.9^{\mathrm{abc}} & 5.0^{\text {abedef }} \\ \mathrm{Mg}_{2} & 0.7^{\mathrm{a}} & 1.6^{\mathrm{abc}} & 5.0^{\mathrm{abede}} & 0.5^{\mathrm{a}} & 1.5^{\mathrm{ab}} & 3.1^{\text {abede }}\end{array}$

$3 r d$ year

\begin{tabular}{rrrrrrr}
$\mathrm{N}_{1} \mathrm{Mg}_{0}$ & $10.2^{\mathrm{ab}}$ & $22.2^{\mathrm{bc}}$ & $36.0^{\mathrm{ed}}$ & $12.4^{\mathrm{a}}$ & $43.9^{\mathrm{a}}$ & $57.1^{\mathrm{e}}$ \\
$\mathrm{Mg}_{1}$ & $1.4^{\mathrm{a}}$ & $3.6^{\mathrm{a}}$ & $11.1^{\mathrm{ab}}$ & $1.8^{\mathrm{a}}$ & $4.2^{\mathrm{a}}$ & $14.3^{\mathrm{ab}}$ \\
$\mathrm{Mg}_{2}$ & $0.9^{\mathrm{a}}$ & $2.6^{\mathrm{a}}$ & $6.5^{\mathrm{a}}$ & $1.3^{\mathrm{a}}$ & $2.9^{\mathrm{a}}$ & $11.7^{\mathrm{ab}}$ \\
\hline
\end{tabular}

Meaning of index letters same as in Table 1. 
Table 6. Ratio of potassium to the sum of calcium and magnesium $(\mathrm{K} /(\mathrm{Ca}+\mathrm{Mg}))$ in grains and straws.

\begin{tabular}{ccccccc}
\hline & \multicolumn{3}{c}{$\mathrm{Ca}_{1}$} & & \multicolumn{3}{c}{$\mathrm{Ca}_{3}$} \\
\cline { 2 - 7 } \cline { 5 - 7 } & $\mathrm{K}_{2}$ & $\mathrm{~K}_{2}$ & & $\mathrm{~K}_{1}$ & $\mathrm{~K}_{2}$ & $\mathrm{~K}_{4}$ \\
\hline
\end{tabular}

\section{Grains}

$\begin{array}{rllllll}1 \text { st year } & & & & & \\ \mathrm{N}_{1} \mathrm{Mg}_{0} & 0.8^{\text {be }} & 0.8^{\text {be }} & 1.0^{\mathrm{d}} & 0.8^{\text {be }} & 0.8^{\text {ed }} & 0.9^{\text {ed }} \\ \mathrm{Mg}_{1} & 0.7^{\text {ab }} & 0.8^{\text {be }} & 0.9^{\text {ed }} & 0.8^{\text {be }} & 0.8^{\text {be }} & 0.9^{\text {ed }} \\ \mathrm{Mg}_{2} & 0.7^{\text {ab }} & 0.8^{\text {be }} & 0.9^{\text {ed }} & 0.7^{\text {ab }} & 0.8^{\text {be }} & 0.9^{\text {ed }} \\ \mathrm{N}_{2} \mathrm{Mg}_{0} & 0.8^{\text {be }} & 0.9^{\text {ed }} & 1.0^{\mathrm{d}} & 0.8^{\text {be }} & 0.9^{\text {ed }} & 1.0^{\text {d }} \\ M_{1} & 0.7^{\text {ab }} & 0.9^{\text {ed }} & 0.9^{\text {ed }} & 0.7^{\text {ab }} & 0.8^{\text {be }} & 0.9^{\text {ed }} \\ \mathrm{Mg}_{2} & 0.7^{\text {ab }} & 0.8^{\text {be }} & 0.9^{\text {ed }} & 0.6^{\text {a }} & 0.8^{\text {be }} & 0.9^{\text {ed }}\end{array}$

2nd year

$\begin{array}{rllllll}\mathrm{N}_{1} \mathrm{Mg}_{0} & 1.5^{\text {ede }} & 1.7^{\mathrm{de}} & 2.2^{\mathrm{f}} & 1.4^{\mathrm{ed}} & 1.6^{\mathrm{de}} & 1.8^{\mathrm{e}} \\ \mathrm{Mg}_{1} & 1.1^{\mathrm{abe}} & 1.2^{\mathrm{ab}} & 1.4^{\mathrm{ed}} & 1.1^{\mathrm{abe}} & 1.1^{\mathrm{abe}} & 1.3^{\mathrm{bed}} \\ \mathrm{Mg}_{2} & 1.0^{\mathrm{ab}} & 1.0^{\mathrm{ab}} & 1.3^{\mathrm{b}} & 1.1^{\mathrm{abe}} & 1.1^{\mathrm{abe}} & 1.3^{\text {bed }} \\ \mathrm{N}_{2} \mathrm{Mg}_{0} & 1.3^{\mathrm{bed}} & 1.8^{\mathrm{e}} & 2.3^{\mathrm{e}} & 1.1^{\mathrm{abe}} & 1.8^{\mathrm{e}} & 1.6^{\mathrm{de}} \\ \mathrm{Mg}_{1} & 0.9^{\mathrm{ab}} & 1.0^{\mathrm{ab}} & 1.2^{\mathrm{abe}} & 0.9^{\mathrm{ab}} & 1.1^{\mathrm{ab}} & 1.1^{\mathrm{abe}} \\ \mathrm{Mg}_{2} & 0.8^{\mathrm{a}} & 0.9^{\mathrm{ab}} & 1.0^{\mathrm{ab}} & 0.8^{\mathrm{a}} & 1.0^{\mathrm{ab}} & 1.1^{\mathrm{abe}}\end{array}$

\section{3 rd year}

$\begin{array}{rllllll}\mathrm{N}_{1} \mathrm{Mg}_{0} & 1.5^{\mathrm{ed}} & 1.6^{\mathrm{d}} & 1.3^{\mathrm{bed}} & 0.8^{\mathrm{a}} & 1.3^{\mathrm{bed}} & - \\ \mathrm{Mg}_{1} & 1.1^{\mathrm{ab}} & 1.1^{\mathrm{ab}} & 1.1^{\mathrm{ab}} & 1.1^{\mathrm{ab}} & 1.1^{\mathrm{ab}} & 1.2^{\mathrm{abe}} \\ \mathrm{Mg}_{2} & 1.0^{\mathrm{ab}} & 1.0^{\mathrm{ab}} & 1.0^{\mathrm{ab}} & 1.1^{\mathrm{ab}} & 1.1^{\mathrm{ab}} & 1.1^{\mathrm{ab}}\end{array}$

Straws

\begin{tabular}{|c|c|c|c|c|c|c|}
\hline \multicolumn{7}{|c|}{ 1st year } \\
\hline $\mathrm{N}_{1} \mathrm{Mg}_{0}$ & $0.2^{\mathrm{b}}$ & $0.4^{d}$ & $1.2^{1}$ & $0.1^{\mathrm{a}}$ & $0.3^{\mathrm{e}}$ & $0.8 \mathrm{~g}$ \\
\hline $\mathrm{Mg}_{1}$ & $0.2^{\mathrm{b}}$ & $0.4^{d}$ & $1.3 \mathrm{~s}$ & $0.1^{\mathrm{a}}$ & $0.3^{\mathrm{e}}$ & $0.7^{\mathrm{t}}$ \\
\hline $\mathrm{Mg}_{2}$ & $0.2^{\mathrm{b}}$ & $0.5^{e}$ & $1.1^{\mathrm{h}}$ & $0.1^{\mathrm{a}}$ & $0.3^{\mathrm{e}}$ & $0.7^{t}$ \\
\hline $\mathrm{N}_{2} \mathrm{Mg}_{0}$ & $0.2^{\mathrm{b}}$ & $0.3^{\circ}$ & $0.7^{t}$ & $0.1^{\mathrm{a}}$ & $0.2^{\mathrm{b}}$ & $0.4^{\mathrm{d}}$ \\
\hline $\mathrm{Mg}_{1}$ & $0.1^{\mathrm{a}}$ & $0.3^{\mathrm{e}}$ & $0.8 \mathrm{~g}$ & $0.1^{\mathrm{a}}$ & $0.2^{\mathrm{b}}$ & $0.5^{e}$ \\
\hline $\mathrm{Mg}_{2}$ & $0.2^{\mathrm{b}}$ & $0.3^{\mathrm{e}}$ & $0.8^{\mathrm{g}}$ & $0.1^{\mathrm{a}}$ & $0.2^{\mathrm{b}}$ & $0.4^{d}$ \\
\hline \multicolumn{7}{|c|}{ 2nd year } \\
\hline $\mathrm{N}_{1} \mathrm{Mg}_{0}$ & $0.5^{\mathrm{ab}}$ & $1.1^{\mathrm{d}}$ & $3.8^{\mathrm{s}}$ & $0.3^{\mathrm{ab}}$ & $0.7^{\mathrm{be}}$ & $2.8^{\mathrm{h}}$ \\
\hline $\mathrm{Mg}_{1}$ & $0.4^{\mathrm{ab}}$ & $1.0^{\mathrm{d}}$ & $3.7 \mathrm{~s}$ & $0.2^{\mathrm{a}}$ & $0.6^{\mathrm{be}}$ & $2.3 \mathrm{~g}$ \\
\hline $\mathrm{Mg}_{2}$ & $0.3^{\mathrm{ab}}$ & $0.9^{\mathrm{e}}$ & $3.2^{1}$ & $0.2^{\mathrm{a}}$ & $0.7^{\mathrm{be}}$ & $2.1 \mathrm{~g}$ \\
\hline $\mathrm{N}_{2} \mathrm{Mg}_{0}$ & $0.7^{\mathrm{be}}$ & $1.4^{\mathrm{e}}$ & $3.0^{\mathrm{ht}}$ & $0.2^{\mathrm{a}}$ & $0.6^{\mathrm{be}}$ & $2.1 \mathrm{~g}$ \\
\hline $\mathrm{Mg}_{1}$ & $0.3^{\mathrm{ab}}$ & $0.4^{\mathrm{ab}}$ & $1.8^{\mathrm{f}}$ & $0.1^{\mathrm{a}}$ & $0.3^{\mathrm{ab}}$ & $1.1^{\mathrm{d}}$ \\
\hline $\mathrm{Mg}_{2}$ & $0.2^{\mathrm{a}}$ & $0.5^{\mathrm{ab}}$ & $1.6^{\mathrm{et}}$ & $0.1^{\mathrm{a}}$ & $0.4^{\mathrm{ab}}$ & $1.0^{\mathrm{d}}$ \\
\hline \multicolumn{7}{|c|}{$3 r d$ year } \\
\hline $\mathrm{N}_{1} \mathrm{Mg}_{0}$ & $0.9^{\mathrm{ab}}$ & $2.2^{\text {bed }}$ & $3.4^{\text {de }}$ & $0.4^{\mathrm{a}}$ & $1.7 \mathrm{abe}$ & $2.1^{\text {bed }}$ \\
\hline $\mathrm{Mg}_{1}$ & $0.5^{\mathrm{a}}$ & $1.3^{\mathrm{ab}}$ & $3.7^{\mathrm{de}}$ & $0.5^{\mathrm{a}}$ & $1.3^{\mathrm{ab}}$ & $3.9^{\mathrm{e}}$ \\
\hline $\mathrm{Mg}_{2}$ & $0.5^{\mathrm{a}}$ & $1.2^{\mathrm{ab}}$ & $2.8^{\text {ede }}$ & $0.4^{\mathrm{a}}$ & $1.1^{\mathrm{ab}}$ & $4.0^{\mathrm{e}}$ \\
\hline
\end{tabular}

Meaning of index letters same as in Table 1. 
Table 7. Magnesium uptake ( $\mathrm{Mg} \mathrm{mg} /$ pot, grains + straws).

\begin{tabular}{|c|c|c|c|c|c|c|c|}
\hline & & \multicolumn{3}{|c|}{$\mathrm{Ca}_{1}$} & \multicolumn{3}{|c|}{$\mathrm{Ca}_{3}$} \\
\hline & & $\mathrm{K}_{1}$ & $\mathrm{~K}_{2}$ & $\mathrm{~K}_{4}$ & $\mathrm{~K}_{1}$ & $\mathrm{~K}_{2}$ & $\mathrm{~K}_{4}$ \\
\hline \multicolumn{8}{|c|}{1 st year } \\
\hline \multirow{3}{*}{$\mathrm{N}_{1}$} & $\mathrm{Mg}_{0}$ & $62^{\mathrm{a}}$ & 73abed & $70^{\mathrm{abe}}$ & $82^{\text {bedef }}$ & $91^{\mathrm{tgh}}$ & 100 ghis \\
\hline & $\mathrm{Mg}_{1}$ & $98^{\mathrm{fghi}}$ & $115^{\prime}$ & $98^{\text {fghi }}$ & $132^{\mathrm{k}}$ & $158^{1 \mathrm{~m}}$ & $148^{\mathrm{k} \operatorname{lm}}$ \\
\hline & $\mathrm{Mg}_{2}$ & $115^{j}$ & $136^{k}$ & $116^{j}$ & $150^{\mathrm{mn}}$ & $176^{\circ}$ & $175^{\text {no }}$ \\
\hline \multirow[t]{4}{*}{$\mathrm{N}_{2}$} & $\mathrm{Mg}_{0}$ & $67^{a b}$ & $90^{\text {efgh }}$ & $88^{\text {defg }}$ & $85^{\text {edefg }}$ & $104^{\text {hij }}$ & $113^{44}$ \\
\hline & $\mathrm{Mg}_{1}$ & $110^{1 j}$ & $152^{1 \mathrm{~m}}$ & $152^{1 \mathrm{~m}}$ & $143^{\mathrm{k} 1}$ & 193p & $213 q$ \\
\hline & $\mathrm{Mg}_{2}$ & $147^{k}$ & $189^{\circ p}$ & $180^{\circ \mathrm{p}}$ & $176^{\circ}$ & $232^{r}$ & $267^{s}$ \\
\hline & $2 a d y$ & & & & & & \\
\hline \multirow{3}{*}{$\mathrm{N}_{1}$} & $\mathrm{Mg}_{0}$ & 27 abe & $31^{\mathrm{bc}}$ & $25^{\mathrm{abc}}$ & $28^{a b e}$ & $36^{\mathrm{e}}$ & $36^{e}$ \\
\hline & $\mathrm{Mg}_{1}$ & $87^{e}$ & $89^{e}$ & $66^{d}$ & $122^{\mathrm{fg}}$ & $128^{\text {hij }}$ & $100^{e f}$ \\
\hline & $\mathrm{Mg}_{2}$ & $124 \mathrm{ghl}$ & $120 \mathrm{ghi}$ & $87^{e}$ & $148^{k 1}$ & $148^{k l}$ & $115^{\mathrm{fgh}}$ \\
\hline \multirow{4}{*}{$\mathrm{N}_{2}$} & $\mathrm{Mg}_{0}$ & $25^{\mathrm{abe}}$ & $18^{\mathrm{ab}}$ & $11^{\mathrm{a}}$ & $30 \mathrm{abe}$ & $15^{\mathrm{a}}$ & $13^{\mathrm{a}}$ \\
\hline & $\mathrm{Mg}_{1}$ & $92^{\mathrm{e}}$ & $129^{\text {his }}$ & $109^{\mathrm{fg}}$ & $142^{\mathrm{jk}}$ & $148^{\mathrm{k} 1}$ & $168^{\mathrm{m}}$ \\
\hline & $\mathrm{Mg}_{2}$ & $130^{\text {his }}$ & $159^{1 m}$ & $134^{i j k}$ & $195^{n}$ & $173^{\mathrm{m}}$ & $222^{\circ}$ \\
\hline & $3 r d y$ & & & & & & \\
\hline \multirow{3}{*}{$\mathrm{N}_{1}$} & $\mathrm{Mg}_{0}$ & $10^{\mathrm{a}}$ & $9^{a}$ & $3^{a}$ & $8^{\mathrm{a}}$ & $3^{\mathrm{a}}$ & $1^{\mathrm{a}}$ \\
\hline & $\mathrm{Mg}_{1}$ & $87^{e}$ & $79 e$ & $43^{b}$ & 99ede & 109de & $82^{\mathrm{c}}$ \\
\hline & $\mathrm{Mg}_{2}$ & $115^{e}$ & $94 \mathrm{ed}$ & $52^{\mathrm{b}}$ & $143^{\mathrm{f}}$ & $141^{f}$ & $101^{\text {ede }}$ \\
\hline
\end{tabular}

Meaning of index letters same as in Table 1.

The increase in the rate of potassium fertilization from $\mathrm{K}_{1}$ to $\mathrm{K}_{2}$ increased significantly the magnesium uptake of yields in the first year at all rates of magnesium fertilization, since the grain and the straw yields increased and the changes in the magnesium content were slight. The uptake of magnesium by the crops which had been produced with the two greatest amounts of potassium varied. In the second and the third years the greatest rate of potassium application depressed the uptake of magnesium with respect to that with the medium rate of potassium, when the plants received a magnesium fertilization. Without the magnesium fertilization the potassium quantities did not affect the uptake of magnesium by the second and the third years' yields.

The increase of the ratio potassium to magnesium in the fertilization depressed significantly the uptake of magnesium by the straws. The amount of magnesium possessed by the grains did not depend equally evidently on the $\mathrm{K} / \mathrm{Mg}$ ratio in the fertilizer. In all the data the results are the following:

\begin{tabular}{cccccc}
\multicolumn{5}{c}{$\mathrm{K} / \mathrm{Mg}$ in fertilization } \\
$\mathrm{K}_{1} / \mathrm{Mg}_{2}$ & $\mathrm{~K}_{1} / \mathrm{Mg}_{1}$ & $\mathrm{~K}_{2} / \mathrm{Mg}_{2}$ & $\mathrm{~K}_{2} / \mathrm{Mg}_{1}$ & $\mathrm{~K}_{4} / \mathrm{Mg}_{2}$ & $\mathrm{~K}_{4} / \mathrm{Mg}_{1}$ \\
0.32 & 0.65 & 0.65 & 1.29 & 1.29 & 2.58 \\
\multicolumn{5}{c}{$\mathrm{Mg} \mathrm{mg} /$ pot } \\
$48^{\mathrm{ab}}$ & $42^{\mathrm{a}}$ & $59^{\mathrm{b}}$ & $56^{\mathrm{b}}$ & $62^{\mathrm{b}}$ & $58^{\mathrm{b}}$ \\
$98^{\mathrm{b}}$ & $69^{\mathrm{a}}$ & $98^{\mathrm{b}}$ & $74^{\mathrm{a}}$ & $83^{\mathrm{ab}}$ & $60^{\mathrm{a}}$ \\
$146^{\mathrm{bc}}$ & $111^{\mathrm{a}}$ & $157^{\mathrm{c}}$ & $130^{\mathrm{ab}}$ & $145^{\mathrm{bc}}$ & $118^{\mathrm{ab}}$
\end{tabular}


Tripling the rate of lime application increased significantly the uptake of magnesium in the first year at all the levels of magnesium, potassium and nitrogen fertilization. In the second and the third years an increase in liming did not affect the magnesium uptake by yields obtained without magnesium. Also an increase in the rate of nitrogen fertilization advanced the uptake of magnesium by plants which had received a magnesium fertilization.

During three years (at the $\mathrm{N}_{1}$-level) the yields of oats took up a total of $98-137 \mathrm{mg} /$ pot of magnesium from the peat itself, and correspondingly during two years (at the $\mathrm{N}_{2}$-level) $92-126 \mathrm{mg} /$ pot. These quantities correspond to $40-55$ and $37-50 \mathrm{mg}$ magnesium with respect to $100 \mathrm{~g}$ of air-dry peat. The peat used in the experiment contained $50 \mathrm{mg} / 100 \mathrm{~g}$ of exchangeable magnesium. Since the peat contained at the end of the test $8-17 \mathrm{mg} / 100 \mathrm{~g}$ of exchangeable magnesium, the plants had taken up also "nonexchangeable" magnesium. The effects of the lime application and the potassium fertilization on the consequent reduction of the "nonexchangeable" reserve of magnesium in the peat were small, as the following results indicate:

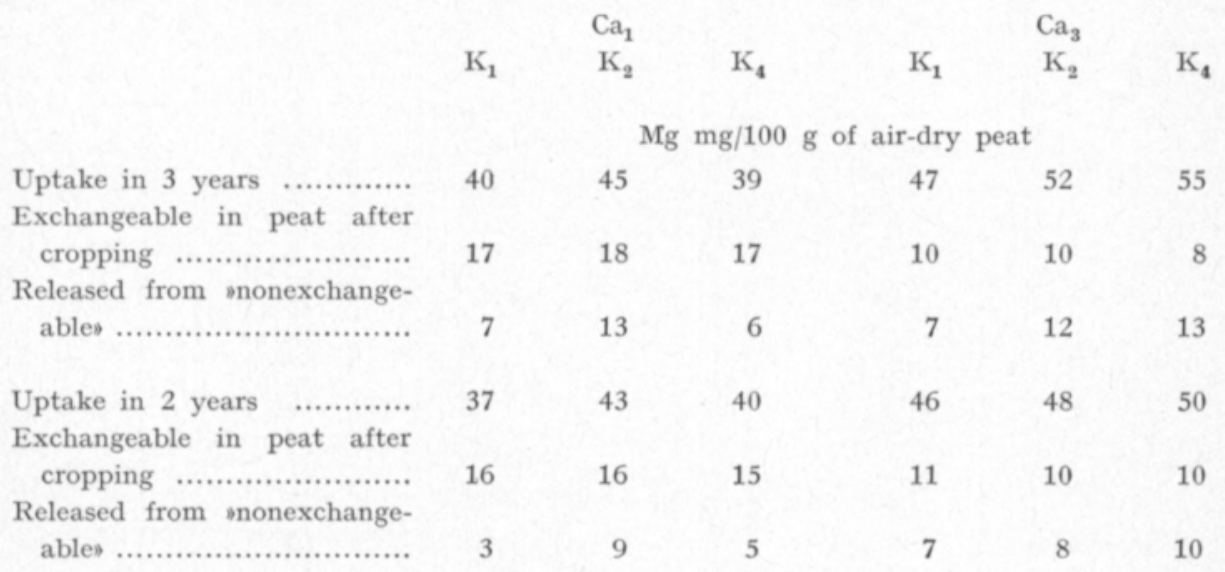

The crops which had been produced by abundant nitrogen fertilization took up from the peat in two years almost as much magnesium as the crops produced by small amounts of nitrogen did in three years. Also, the consumption of the "nonexchangeable" magnesium reserves was almost equal at both rates of nitrogen fertilization.

\section{Uptake of the fertilizer magnesium}

In general, the oats took up the more fertilizer magnesium $\left(\mathrm{Mg}_{1}-\mathrm{Mg}_{0}\right.$, $\mathrm{Mg}_{2}-\mathrm{Mg}_{0}$ ) the more magnesium fertilizer had been supplied (Table $\mathbf{8}$ ). There was, however, no significant difference in the magnesium contents of the yields which had received two different rates of magnesium fertilization with a low rate of lime application, a small rate of nitrogen, and an abundant rate of potassium fertilization.

The oats took up less magnesium supplied in the fertilizer at the greatest rate of potassium than at the intermediate rate of fertilization. At the rate 
Table 8. Fertilizer magnesium uptake (mg/pot and \%, grains + straws).

\begin{tabular}{|c|c|c|c|c|c|c|}
\hline & \multicolumn{3}{|c|}{$\mathrm{Ca}_{1}$} & \multicolumn{3}{|c|}{$\mathrm{Ca}_{3}$} \\
\hline & $\mathrm{K}_{1}$ & $\mathrm{~K}_{2}$ & $\mathrm{~K}_{4}$ & $\mathrm{~K}_{1}$ & $\mathrm{~K}_{2}$ & $\mathrm{~K}_{4}$ \\
\hline In 3 years & \multicolumn{6}{|c|}{$\mathrm{Mg} \mathrm{mg/pot}$} \\
\hline $\mathrm{N}_{1} \mathrm{Mg}_{1}$ & 174 & 170 & 110 & 227 & 265 & 194 \\
\hline $\mathrm{Mg}_{2}$ & 253 & 242 & 157 & 387 & 334 & 253 \\
\hline \multicolumn{7}{|l|}{ In 2 years } \\
\hline $\mathrm{N}_{2} \mathrm{Mg}_{1}$ & 110 & 173 & 165 & 181 & 220 & 257 \\
\hline $\mathrm{Mg}_{2}$ & 185 & 242 & 214 & 257 & 286 & 360 \\
\hline In 3 years & \multicolumn{6}{|c|}{$\%$} \\
\hline $\mathrm{N}_{1} \mathrm{Mg}_{1}$ & 29 & 28 & 18 & 38 & 44 & 32 \\
\hline $\mathrm{Mg}_{2}$ & 21 & 20 & 13 & 32 & 28 & 20 \\
\hline \multicolumn{7}{|l|}{ In 2 years } \\
\hline $\mathrm{N}_{2} \mathrm{Mg}_{1}$ & 28 & 43 & 41 & 45 & 55 & 64 \\
\hline $\mathrm{Mg}_{2}$ & 23 & 30 & 27 & 32 & 36 & 45 \\
\hline
\end{tabular}

The total amount of fertilizer magnesium supply ( $\mathrm{Mg} \mathrm{mg} / \mathrm{pot})$ :

$\begin{array}{llr} & \mathrm{Mg}_{1} & \mathrm{Mg}_{2} \\ \text { In 3 years } & 600 & 1200 \\ \text { In 2 years } & 400 & 800\end{array}$

of abundant liming and of abundant nitrogen fertilization the uptake of magnesium increased upon increasing the rate of potassium fertilization.

A tripled rate of lime application enhanced the utilization of the fertilizer magnesium at the rate of abundant nitrogen fertilization. Similarly, an increase in the nitrogen fertilization increased the amount of magnesium taken up from the fertilizer at all the rates of potassium and magnesium fertilization and of liming.

Of the annually suplied $200 \mathrm{mg}$ of fertilizer magnesium the oats took up $45-64 \%$ at the abundant rate of liming and of nitrogen fertilization. Of the double rate of magnesium fertilizer supply the oats took up correspondingly $32-45 \%$.

\section{Discussion}

The magnesium content of the oat grains obtained in this pot experiment was nearly the same as the magnesium content of oat grains obtained in other pot (Sorteberg 1974) or field (Jokinen and Simojoki 1975) experiments. The variation in the magnesium content was small. A $0.1 \mathrm{mg} / \mathrm{g}$ change in the magnesium content, caused by the magnesium fertilization, was already statistically significant. This result indicates that the magnesium content of grains varies generally within narrow limits (JokINEN and SIMojoki 1975). 
The magnesium treatments caused more readily a change in the magnesium content than in the crop yield. Only a very low magnesium content in the growth base limited the yield (JokINen 1977). In several experiments (VIGerust 1966, Birch et al. 1966, Sorteberg 1975) the conclusion has been reached that magnesium fertilization does not affect the yield of cereals, but increases the magnesium content of the plants. In these experiments, carried out on mineral and peat soils, the magnesium content of the growth base was probably not so low as to retard the growth of the crop.

Upon increasing the rate of magnesium fertilizer the yield of the crop reached its maximum at a lower rate of magnesium application than the magnesium content of the grains and the straws. The same has been noted by, among others, Alston (1966 b) and Jacoues et al. (1975).

Upon increasing the rate of magnesium fertilization the magnesium content of the straws increased even after the maximum yield has been reached. Even though BENKo and FECENKo (1970) used in their solution-culture experiments nutrient solutions of magnesium contents varying in the range of $0-10$ me/l the increase in the magnesium content of 30 days old barley shoots did not stop. The positive effect which magnesium fertilization has on increasing the magnesium content of stalks and leaves of plants is of advantage when cultivating grasses for animal forage. The low magnesium content or too high a value of the ratio $\mathrm{K} /(\mathrm{Ca}+\mathrm{Mg})$ in the forage have been mentioned as some of the causes of grass tetany in livestock (KEMP and t'HART 1957).

The potassium and the calcium contents of yields (grains, straws) obtained without magnesium fertilization were higher than the corresponding contents of crops that had received a magnesium fertilization. Similarly, the ratios $\mathrm{K} / \mathrm{Mg}$ and $\mathrm{K} /(\mathrm{Ca}+\mathrm{Mg})$ were high in grains as well as in the straws without magnesium fertilization. Causes of the high potassium and calcium contents were probably the insufficiency of the magnesium reserves available to the plants and the consequent substitution of the missing magnesium by the potassium and the calcium (Grimme et al. 1974, Terman et al. 1975). The substitution was at its strongest in the second and the third years when there was little magnesium avaliable to the oats. JERLSTRöm (1975) noted in his pot experiments that also deficient potassium was substituted for by magnesium, among other cations. Nothing corresponding was noted in the present data.

The interdepandence between the potassium and magnesium contents in the grains was not significant. Apparently potassium does not hinder the movement of magnesium in the plants from the stalks and the leaves to the grains. The same conclusion is suggested by the fact that the amount of magnesium taken up by the grains did not depend on the rate of potassium fertilization nor the ratio of potassium to magnesium supplied in the fertilizers.

The rate of potassium given along with the magnesium fertilization increased the straw yield and the potassium content of the straws, but depressed the magnesium content. The decrease in the magnesium content may, in part (at the $\mathrm{K}_{1}$ and $\mathrm{K}_{2}$ rates), be caused by the same amount of magnesium having been taken up by plants of low or high yield; i.e., by the relative dilution of the yield (JAnsson 1971, Grimme et al. 1974). Upon adding potassium fertilizer from $\mathrm{K}_{2}$ to $\mathrm{K}_{4}$ the quantity of magnesium taken up by the 
straws was diminished. Thus, an ample potassium fertilization impeded the uptake of magnesium by the oats. FAlade (1973) and TERMan et al. (1975) also noted in their experiments that the antagonism between potassium and magnesium has a significant role only when an abundant potassium fertilization was being used. The significant negative correlation between the potassium and magnesium contents in straws, and the negative effect which an increase in the ratio of potassium to magnesium in fertilization has on the magnesium content of the straws and on the uptake of magnesium by straw crop, further show that the antagonism between potassium and magnesium has as its only real consequence in oats changes in the nutrient contents and in the nutrient uptakes of straws.

Calcium moves with difficulty in plants from the stalks and leaves to the grains (JACQUES et al. 1975). Therefore, tripling the rate of liming did not increase significantly the calcium content of the grains. When there was an insufficiency of magnesium a part of the missing magnesium had been substituted by calcium. In other instances these nutrients did not affect each others' translocation into the grains. An addition of lime promoted the uptake of magnesium by oat straws (FALADE 1973), and advanced the fertilizer magnesium uptake. This is understandable since the growth base was acid.

An increase in the rate of nitrogen fertilization increased the amount of magnesium taken up by the straws, and promoted the uptake of fertilizer magnesium. The potassium content of the straws, on the other hand, decreased, and concomitantly the potassium to magnesium ratio $(\mathrm{K} / \mathrm{Mg})$ and the ratio $\mathrm{K} /(\mathrm{Ca}+\mathrm{Mg})$ decreased. Mäntylahti, and MarJanen (1971) noted that adding to the nitrogen fertilization lowered the last mentioned ratio of cations in grass harvested for silage.

\section{REFERENCES}

Alston, A. M. 1966 a. The influence of $\mathrm{N}$ and $\mathrm{Mg}$ fertilizer and $\mathrm{CaCO}_{3}$ on the absorption of $\mathrm{Mg}$ by oats. J. Agric. Sci. 66: $61-66$.

- $1966 \mathrm{~b}$. The effects of limestone, $\mathrm{N}, \mathrm{K}$ and $\mathrm{Mg}$ fertilizers on $\mathrm{Mg}$ absorption by oats and barley. J. Agric. Sci. 67: 1-6.

Benko, V. \& Fecenko, J. 1970. Effect of various K: Mg ratios upon the formation of dry matter and the uptake of nutrients by spring barley. Acta Fytotechnica 21: 91-104.

Birch, J. A., Devine, J. R. \& Holmes, M. R. J. 1966. Field experiments on the magnesium requirements of cereals, potatoes and sugar beet in relation to nitrogen and potassium application. J. Sci. Food Agric. 17: 76-81.

FALADE, J. A. 1973. Interrelationships between potassium, calcium and magnesium nutrition of Zea mays L. Ann. Bot. 37: 345-353.

Grimme, H., Braunschweig, L. C. von \& NÉmeth, K. 1974. Beziehungen zwischen Kalium, Calcium und Magnesium bei Aufnahme und Ertragsbildung. Landw. Forsch. Sonderh. 30/II: $93-100$.

HANSEN, E. M. 1972. Studies on the chemical composition of isolated soil solution and the cation absorption by plants I. Relationship between form and amount of added nitrogen and absorption of $\mathrm{N}, \mathrm{K}, \mathrm{Na}, \mathrm{Ca}$ and $\mathrm{Mg}$ by barley. Plant Soil 37: 589-607.

HÅlAND, Å. 1971. Verknad av kalium, magnesium, kalk og nitrogen in markforsøk i sørvest Norge. Forsk. Fors. Landbr. 22: 1-20. 
Jacoues, G. L., VANderlip, R. L. \& Whitney, D. A. 1975. Growth and nutrient accumulation and distribution in grain sorghum I. Dry matter production and $\mathrm{Ca}$ and $\mathrm{Mg}$ uptake and distribution. Agron. J. 67: 607-616.

Jansson, S. L. 1971. Naturalness of commercial fertilizers. An ecological treatise. Acta Agr. Fenn. 123: 173-185.

JERLström, H.-G. 1975. Studies över möjligheterna att med växt- och jordanalyser beskriva magnesiumsituationen i svensk växtodling. Diss. 175 p. Uppsala.

Jokinen, R. 1977. Effect of added magnesium, potassium, lime and nitrogen on oats I. Yields. J. Scient. Agric. Soc. Finl. 49: 283-295.

_- - \& Sıмојокі, P. 1975. Magnesiumlannoitus viljanviljelyssä. Referat: Magnesiumgödsling vid spannmâlsodling. Kehittyvä Maatalous 27: 22-29.

JørgensEn, I. 1976. Kvaelstof, fosfor, kalium og magnesium til Lammefjordens inadaemmede arealer. Tidsskrift Planteavl 80: 713-741.

Kemp, A. \& t'Hart, M. L. 1957. Grass tetany in grazing milking cows. Neth. J. Agric. Sci. 5: 4-17.

LEHNE, I. \& KOEPKE, V. 1962. Die Wirkung verschiedener Stickstoffformen auf magnesiumarmen Sandboden. Albrecht-Thaer-Archiv 6: 269-276.

Mengel, K., Viro, M. \& Hehl, G. 1976. Effect of potassium on uptake and incorporation of ammonium-nitrogen of rice plants. Plant Soil 44: 547-558.

Mäntylahti, V. \& Marjanen, H. 1971. Tuorerehunurmen lannoitus. Summary: Fertilization of leys for silage. Ann. Agric. Fenn. 10: 153-173.

SORTEBERG, A. 1974. Virkning av magnesium på avlingsstørrelse og magnesiuminnhold ved ulike kalking og ulike nitrogenforbindelser. Forsk. Fors. Landbr. 25: 537-558.

Terman, G. L., Allen, S. E. \& Bradford, B. N. 1975. Nutrient dilution-antagonism effects in corn and snap beans in relation to rate and source of applied potassium. Soil Sci. Soc. Amer. Proc. 39: 680-685.

Welte, E. \& Werner, W. 1963. Potassium-magnesium antagonism in soils and crops. J. Sci. Food Agric. 14: 180-186.

Vigerust, E. 1966. Noen gjødselvirkninger på jord og plantevekst i rammeforsøk. Forsk. Fors. Landbr. 17: 195-207.

Ms received November 9, 1977

\title{
SELOSTUS
}

\section{Magnesium-, kalium- ja typpilannoituksen sekä kalkituksen vaikutus II. Kauran ravinnepitoisuuksiin, kationien suhteeseen ja magnesiumin ottoon}

\author{
RAILI JOKINEN \\ Maatalouden tutkimuskeskus, Maanviljelyskemian ja -fysiikan laitos, 01300 Vantaa 30.
}

Kolme kasvukautta jatkuneessa astiakokeessa rahkaturve kasvualustana magnesiumlannoitus $(0,200$ ja $400 \mathrm{mg} \mathrm{Mg/5} 1$ astia) kohotti merkitsevästi kauran jyvien ja olkien magnesiumpitoisuutta. Kaliumlannoituksen lisäys (415, 830 ja $1660 \mathrm{mg} / \mathrm{ast} \mathrm{K}$ ) pienensi merkitsevästi olkien magnesiumpitoisuutta, kun kasvit saivat magnesiumlannoituksen. Magnesiumin puutteessa kaliumlannoitemäärät eivät vaikuttaneet olkien magnesiumpitoisuuteen. Lannoituksena annettujen kolmen kalium- ja kahden magnesiummäärän ekvivalenttien suhteen nousu $(0.32,0.65$, 1.29 ja 2.58) pienensi sekä jyvien että olkien magnesiumpitoisuutta. Magnesiumlannoituksen ohella annetun kalkin lisãys (2400 ja $7200 \mathrm{mg} /$ ast Ca) pienensi jyvien mutta kohotti olkien magnesiumpitoisuutta. Typpilannoituksen lisäys kaksinkertaiseksi (1000 ja $2000 \mathrm{mg} /$ ast N) kohotti jyvien ja olkien magnesiumpitoisuutta, jos kasvit saivat magnesiumlannoituksen. Magnesiumin puutteessa kalkin tai typen lisäys ei vaikuttanut satojen magnesiumpitoisuuteen.

Tutkimuksessa käytetyt magnesium-, kalium- ja typpimäärät eivät vaikuttaneet kauran jyvien kaliumpitoisuuteen. Olkien kaliumpitoisuus nousi kaliummäärää lisättäessä. Ilman magne- 
siumlannoitusta kauran jyvien ja olkien kaliumpitoisuus sekä suhteiden $\mathrm{K} / \mathrm{Mg}$ ja $\mathrm{K} /(\mathrm{Ca}+\mathrm{Mg})$ arvot olivat korkeat. Osa puuttuvasta magnesiumista oli ehkä korvautunut kaliumilla.

Ilman magnesiumlannoitusta saatujen jyvien ja olkien kalsiumpitoisuus oli merkitsevãsti korkeampi kuin magnesiumlannoituksella saatujen satojen kalsiumpitoisuus. Kaura otti puuttuvan magnesiumin tilalle osittain ehkä myös kalsiumia. Kaliumlannoituksen lisäys pienensi kalsiumpitoisuutta, mutta kalkki- tai typpimäärän lisäys kohotti sitä.

Kauran jyvien typpipitoisuus kohosi typpilannoituksen määrää lisättäessä ja pieneni kaliumin määrää lisättäessä. Ilman magnesiumia oljet sisälsivät runsaammin typpeä kuin magnesiumlannoituksen saaneet oljet, koska satojen tuleentuminen viivästyi magnesiumin puutteen vuoksi.

Jyväsadon ottama magnesiummäärä $(\mathrm{mg} / \mathrm{ast} \mathrm{Mg}$ ) oli korkeimmillaankin vain noin puolet koko sadon ottamasta magnesiummäärästä. Kalium-, kalkki- ja typpimäärät tai lannoituksena annettujen kaliumin ja magnesiumin suhde eivät vaikuttaneet jyväsadon magnesiumin ottoon. Olkisadon ottama magnesiummäärä lisääntyi magnesiumin, kalkin tai typen määrää lisăttäessä, mutta väheni runsasta kaliumlannoitusta käytettäessä, jos kalkitus ja typpilannoitus olivat niukat. Kalkin ja typpilannoituksen lisäys tehostivat kumpikin lannoituksena annetun magnesiumin hyväksikäyttöä. Vuosittain annetusta $200 \mathrm{mg}$ :sta magnesiumia kaura käytti hyväkseen runsaan kalkituksen ja typpilannoituksen tasolla $45-64 \%$. 